\begin{tabular}{l|l} 
2. To: (Receiving Organization) & 3. From: (Ori \\
Consequence Analysis (8M400) & Consequenc \\
\hline 5. Proj./Prog-/Dept./Div.: & 6. Cog. Engr.: \\
TWRS FSAR/BIO & B. W. Hall
\end{tabular}

8. Originator Remarks:

The attached document is submitted for approval and release. The attached document shall not be used as the final or sole document for effecting changes to the TWRS authorization basis or safety basis.
11. Receiver Remarks:
11A. Design Baseline Document?
NA

4. Related EDT No.:
NA

7. Purchase Order No.:

NA

9. Equip./Component No.:

NA

10. System/Bldg./Facility:

TWRS

12. Major Assm. Dwg. No.:

NA

13. Permit/Permit Application No.: NA

14. Required Response Date: $9 / 4 / 96$

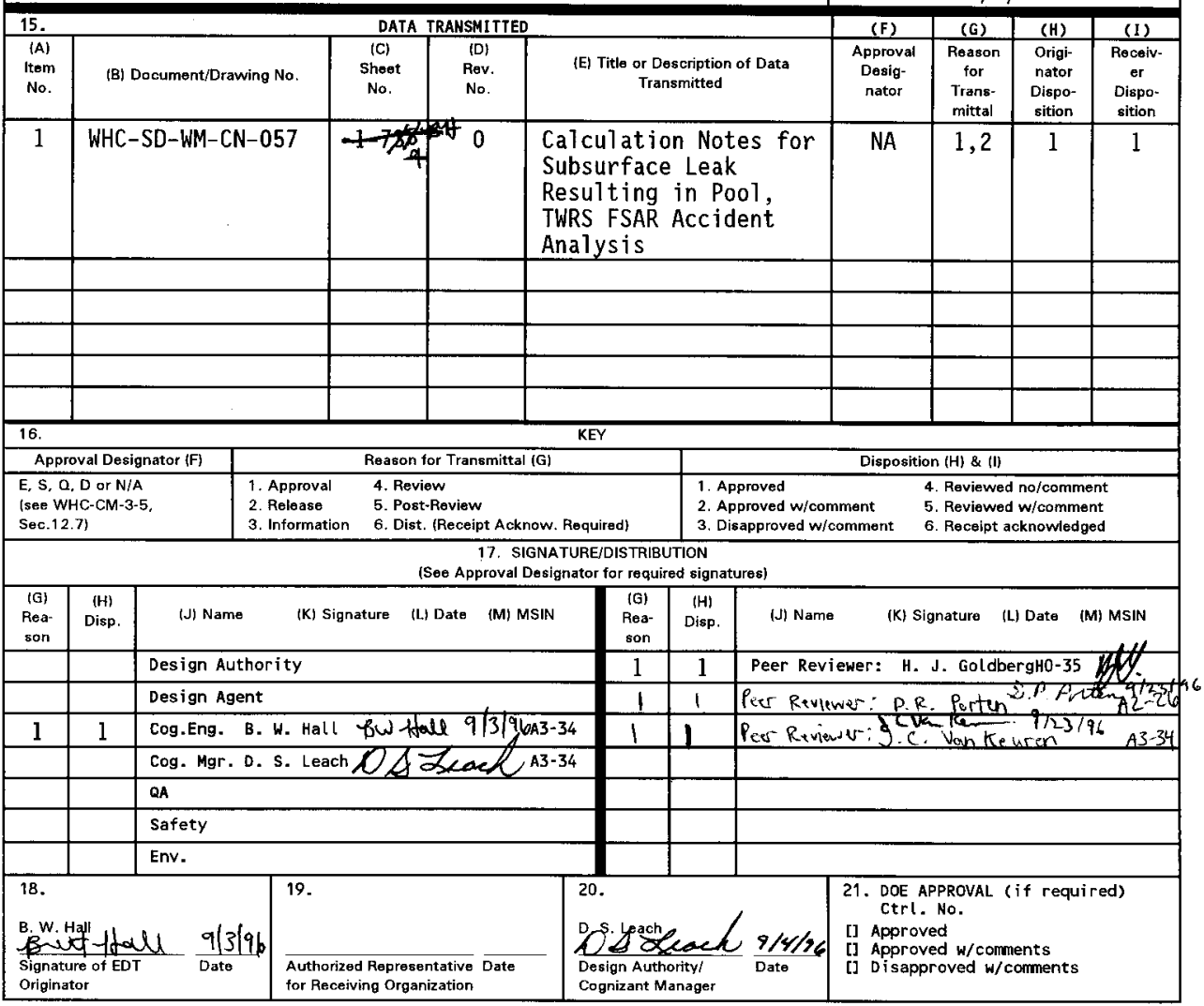




\title{
Calculation Notes for Subsurface Leak Resulting in Pool, TWRS FSAR Accident Analysis
}

\author{
Brett Hall \\ Westinghouse Hanford Company, Richland, WA 99352 \\ U.S. Department of Energy Contract DE-AC06-87RL10930 \\ $\begin{array}{lll}\text { EDT/ECN: } & 619204 & \text { UC: } 510 \\ \text { Org Code: } & 8 \text { M400 } & \text { Charge Code: N1FC3 } \\ \text { B\&R Code: } & \text { EW31220071 } & \text { Total Pages: } 75 \text { \&C }\end{array}$
}

Key Words: resuspension, shine, skyshine, atmospheric dispersion factor, pool, aerosols, particulates, berm, bremmstrahlung radiation

Abstract: This document includes the calculations performed to quantify the risk associated with the unmitigated and mitigated accident scenarios described in the TWRS FSAR for the accident analysis titled: "Subsurface Leaks Resulting in Pool."

TRADEMARK DISCLAIMER. Reference herein to any specific comercial product, process, or service by trade name, trademark, manufacturer, or otherwise, does not necessarily constitute or imply its endorsement, recommendation, or favoring by the United States Government or any agency thereof or its contractors or subcontractors.

Printed in the United States of America. To obtain copies of this document, contact: WHC/BCS Document Control Services, P.O. Box 1970, Mailstop H6-08, Richland WA 99352, Phone (509) 372-2420; Fax (509) 376-4989.
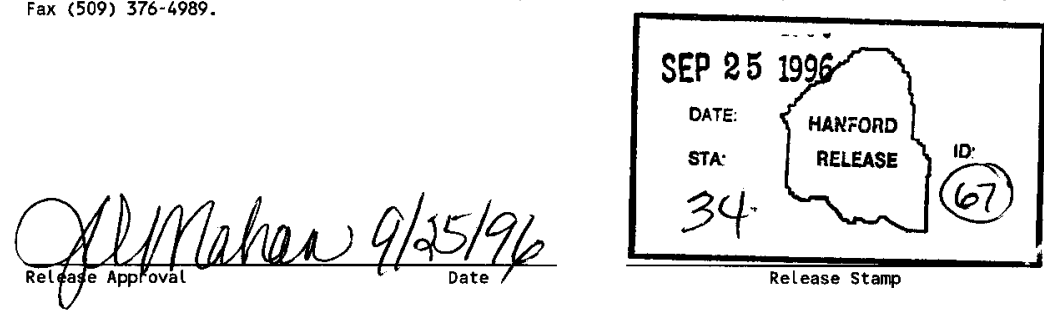

Approved for Public Release 


\section{WHC-SD-WM-CN-057, Rev. 0}

\section{CALCULATION NOTES FOR SUBSURFACE LEAK RESULTING IN POOL, TWRS FSAR ACCIDENT ANALYSIS}

Rev. 0

Safety Analysis and Nuclear Engineering 


\section{WHC-SD-WM-CN-057, Rev. 0}

\section{CONTENTS}

1.0 intRODUCTION.................................. of 79

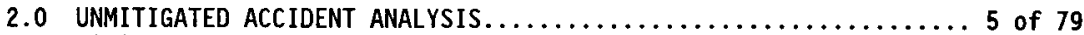

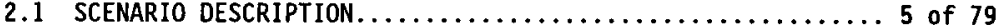

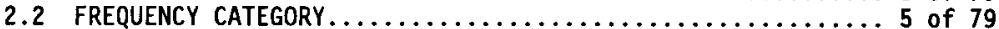

2.3 SOURCE TERM DEVELOPMENT....................... 6 of 79

2.3.1 Waste Inventory and Solids Content............ 6 of 79

2.3.2 Final Surface Pool Volume and Dimensions.........6 of 79

2.3.3 Time Required for Pool to Form.............. 7 of 79

2.3.4 Resuspension Release from Surface of Growing Liquid Pool.............................. 7 of 79

2.3.5 Resuspension Release from Contaminated Soil

After Pool Soaks In..................... 8 of 79

2.3.6 Maximum Release Rate for Estimating

Toxicological Exposures..................... 9 of 79

2.4 CONSEQUENCE ANALYSIS............................... 9 of 79

2.4.1 Onsite and Offsite Receptor Inhalation Dose

Estimates............................ 9 of 79

2.4.2 Offsite Receptor Ingestion Dose Estimate........ 10 of 79

2.4.3 Direct Shine Dose to Onsite Receptor........... Il of 79

2.4.4 Skyshine Dose to Onsite Receptor............... 13 of 79

2.4.5 Summary of Dose Estimates, by Pathway........... 14 of 79

2.4.6 Toxicological Exposure Estimates for the

Onsite and Offsite Receptors................. 14 of 79

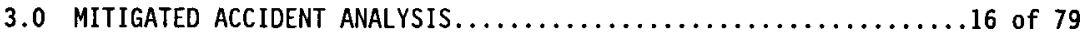

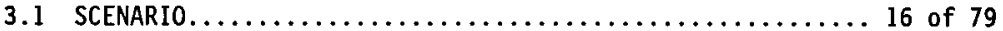

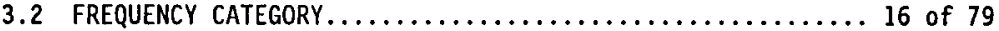

3.3 SOURCE TERM DEVELOPMENT........................ 16 of 79

3.3.1 Final Surface Pool Volume and Dimensions........ 16 of 79

3.3.2 Resuspension Release from Growing

Liquid Pool........................... 17 of 79

3.3.3 Resuspension Release from Contaminated

Ground After Pool Soaks In................. 18 of 79

3.3.4 Maximum Release Rate in Estimating

Toxicological Exposures..................... 18 of 79

3.4 CONSEQUENCE ANALYSIS .......................... 18 of 79

3.4.1 Onsite and Offsite Receptor Inhalation

Dose Estimates.......................... 18 of 79

3.4.2 Offsite Receptor Ingestion Dose Estimate........ 19 of 79

3.4.3 Estimate of Direct Shine Dose to the

Onsite Receptor......................... 19 of 79

3.4.4 Estimate of Skyshine Dose to the Onsite

Receptor............................ 20 of 79

3.4.5 Summary of Mitigated Radiological Dose

Estimate, by Pathway..................... 21 of 79

3.4.6 Toxicological Exposure Estimates for the

Onsite and Offsite Receptors................ 21 of 79 
WHC-SD-WM-CN-057, Rev. 0

4.0 COMPARISON TO EVALUATION GUIDELINES................... 22 of 79

5.0 SUMMARY OF KEY ASSUMPTIONS .......................... 23 of 79

5.1 Key Assumptions, Unmitigated Accident Analysis............23 of 79

5.2 Key Assumptions, Mitigated Accident Analysis............. 24 of 79

6.0 PEER REVIEW..................................... 26 of 79

7.0 RefERENCES.................................... 27 of 79

FIGURES

Figure 2-1. Graph of Resuspension Fraction Vs. Time............ 28 of 79

Figure 2-2. Geometrical Parameters for MICROSKYSHINE Calculations... 29 of 79

TABLES

Table 2-1. Bounding Activity Concentrations, by Waste Type........ 30 of 79

Table 2-2. Unit Liter Doses for Inhalation and Ingestion......... 31 of 79

Table 2-3. Centerline Atmospheric Dispersion Coefficients for

200-Area Tank Farm Acute, Ground Level Releases......... 32 of 79

Table 2-4. Photon Production Rates Entered in the MICROSHIELD

and MICROSKYSHINE Codes, Unmitigated Accident Analysis... 33 of 79

Table 2-5. Summary of Unmitigated Dose Estimates, by Pathway....... 34 of 79

Table 2-6. Sum-of-Fraction of Risk Guidelines for a Unit Release of Chemicals and Gases........................... 35 of 79

Table 3-1. Photon Production Rates Entered in MICROSHIELD and

Table 3-2. Summary of Mitigated Dose Estimates, by Pathway......... 38 of 79

Table 4-1. Consequences of Subsurface Leak Resulting in Pool,

Compared to Evaluation Guidelines................... 38 of 79

\section{APPENDICES}

A Historical Subsurface Leaks from Tank Farm Transfer Lines....... 40 of 79

B Calculation of Maximum Submersible Pump Transfer Flowrate....... 43 of 79

C MICROSHIELD Output Files................................... 49 of 79

D BREMCALC Data........................................ 62 of 79

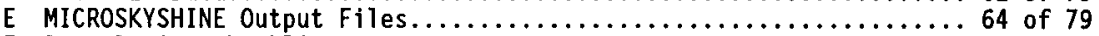

F Peer Review Checklist..................................... 77 of 79 


\section{WHC-SD-WM-CN-057, Rev. 0}

\subsection{INTRODUCTION}

This document contains the calculation notes that support the accident analysis titled "Subsurface Leak Resulting in Pool" in the TWRS FSAR. These calculation notes include the consequence and frequency analys is performed for both the mitigated and unmitigated accident scenarios described in the FSAR. 
WHC-SD-WM-CN-057, Rev. 0

\subsection{UNMITIGATED ACCIDENT ANALYSIS}

\subsection{SCENARIO DESCRIPTION}

The bounding representative accident selected for detailed analysis is a leak from an unencased bermed line during a submersible pump transfer from an SST. The leak is assumed to be catastrophic (i.e., $100 \%$ of pipe flow is assumed to leak into the soil). The leak is postulated to erode away the embankment material. The waste spreads out on the soil surface. It is postulated that the leak occurs when the ambient temperature is significantly below the saturation temperature of the waste. The dissolved salts in the waste crystallize out of solution as the pool spreads, limiting the penetration of waste into the soil. While the pump is running it is assumed the surface of the pool remains liquid.

After the leak is detected and the transfer pump is shut off, it is postulated the remaining liquid waste soaks into the soil. Due to the filtering effect of the soil, the crystallized salts and any entrained solid precipitates carried in the waste stream are postulated to be deposited in the top few centimeters of soil. While the pump is running and the pool is growing, aerosols are resuspended by wind blowing over the liquid surface. After the pump is shutoff and the waste soaks in, particulate surface contamination is resuspended, as the soil dries out. This occurs for an indefinite period of time [unti] the leak site is remediated (e.g., sprayed with water to limit resuspension, covered with grave1)].

The onsite and offsite receptors are exposed to resuspended aerosols and particulates from the liquid pool and contaminated soil. The onsite receptor is also exposed to significant shine and skyshine dose from the liquid pool and contaminated soil. Shine and skyshine dose to the offsite receptor will be negligible due to the distance to that receptor.

\subsection{FREQUENCY CATEGORY}

The initiating event, leak from unencased bermed line, is considered to be an Anticipated event (frequency range 1 to $\mathrm{lE}-2$ events/yr), based on Site experience. The transfer lines used for interim stabilization of SSTs are beyond their intended 5 year design life (WHC-SD-WM-SAR-034 1989). Since these lines are in contact with the soil, they are prone to corrosion failures.

The table in Appendix A lists the events from the occurrence reporting database (between 1972 and 1996) where unencased bermed or buried transfer lines were found to have leaked during waste transfers or pressure testing with water. Eight events occurred over the 24 year period. Four events between 1992 and 1996. The leak frequency over the 1992 to 1996 time frame is judged to be representative of future SST transfers. 
WHC-SD-WM-CN-057, Rev, 0

\subsection{SOURCE TERM DEVELOPMENT}

\subsubsection{Waste Inventory and Solids Content}

Unencased bermed transfer lines will only be used for transfers from

SSTs. The radionucl ide inventory of SST waste, by solids and liquids fractions, are summarized in Table 2-1. The inhalation unit liter dose (ULD) values for the solids and liquids fractions are summarized in Table 2-2.

For this analysis, it is assumed that the waste being transported contains one-third (by volume) entrained solids. This is the maximum solids loading expected during tank waste transfers. This solids loading is conservative because it is above the upper operating limit of the 242-A evaporator $(1 \mathrm{imit}=30$ vol $\%$ solids), which handles the most concentrated waste transported in the tank farms.

\subsubsection{Final Surface Pool Volume and Dimensions}

The size of the pool formed in the unmitigated accident is dependent on several factors, including: the leak flow rate, the topography of the soil, the natural infiltration rate of the soil, the salt content of the waste, the temperature of the waste, and the ambient temperature. Many different leak volumes and pool dimensions can be postulated for the unmitigated accident. Some perspective on the volume and dimensions of a surface pool that can be formed during waste leaks can be gained by examining the occurrence report database. Atlantic Richfield Hanford Company 0ccurrence report 73-78 (available in the DOE reading Room) and ARH-2977 RD (1974) describe an incident where an estimated 8600 gal of waste escaped from an underground pipeline to the soil surface in the $S$ Tank Farm. The flow covered an irregularly shaped area with maximum dimensions of about 50 feet by $200 \mathrm{ft}$. The depth of penetration into the soil varied from about 2 inches to 18 inches. In another incident at the 242-S evaporator (described in Rockwell Occurrence Report ROR-80-2788), an estimated 2000 gallons of waste were released from a buried unencased transfer line. This incident created a surface pool containing an estimated 200 gallons of waste (i.e., $10 \%$ of the subsurface leak surfaced).

Neither of the above described leaks, however, adequately represent the magnitude of a waste leak that can be formed in an unmitigated event. Both leaks were manually detected. At a maximum submersible pump flowrate of 50 gpm (see Section 2.3.2), a 2000 gallon leak could occur in just $40 \mathrm{~min}$, a 8600 gal leak in 2.7 hours.

In an incident described in Rockwell 0ccurrence Report 79-02, raw water was left running inside a service pit in the tank farms. The raw water overflowed the service pit producing a surface pool covering an estimated surface area of $3000 \mathrm{yd}^{2}$ before it was discovered. The leak occurred under freezing conditions. The pool was estimated to contain 37,500 gal of water. 
For the unmitigated accident analysis, it is assumed that the leak ultimately results in a surface poor of waste of the same dimensions as the raw water leak described in Rockwell 0ccurrence Report 79-02. This will result in reasonably conservative dose estimates, as the total leak volume used in the unmitigated accident analysis will be roughly 4 times larger than the largest surface waste leak recorded in the database. Although even larger leak volumes could be postulated, the consequence analysis below shows that the 37,500 gal leak size is sufficient to determine the need for safety class controls. Using the raw water leak incident as a basis, it is assumed the unmitigated waste leak covers a surface area of soil equal to $3000 \mathrm{yd}^{2}$.

For the purposes of estimating shine and skyshine doses the pool is assumed to be circular. The radius of this pool is estimated from the surface area as follows:

$$
r=\left[\left(3000 \mathrm{yd}^{2}\right)(3 \mathrm{ft} / \mathrm{yd})^{2} /(3.14)\right]^{1 / 2}=93 \mathrm{ft}=28 \mathrm{~m}
$$

\subsubsection{Time Required for Pool to Form}

It is postulated that the leak occurs during a submersible pump transfer from an SST. The submersible pumps used for interim stabilization of the SSTs pump at much higher flowrates than the SST saltwell pumps. Appendix B contains a calculation that shows that the maximum flowrate that could be expected in a catastrophic pipe break right outside the pump pit will amount to less than $50 \mathrm{gpm}$ for the submersible pump transfer system used to pump out Tank BX-106.

The minimum amount of time required for the unmitigated surface pool to form can be determined by dividing the assumed total leak volume by the maximum submersible pump flowrate:

Time required for pool to form $=37,500 \mathrm{gal} / 50 \mathrm{gpm}=750 \mathrm{~min}$ or $12.5 \mathrm{~h}$.

\subsubsection{Resuspension Release from Surface of Growing Liquid Pool}

The waste is postulated to spread out as a liquid pool until the pump is shutoff at 12.5 hours. A resuspension release flux of $2 \mathrm{E}-10 \mathrm{~kg} / \mathrm{s}-\mathrm{m}^{2}$ is used to estimate the respirable release from the growing liquid pool. This resuspension flux was estimated from Figure 3-8 in DOE-HDBK-3010-94, corresponding to the mass release for a pond with a $200 \mathrm{~m}$ fetch at wind speeds less than $5 \mathrm{~m} / \mathrm{s}$. This resuspension flux is conservative for this accident where the radius of the pool is $28 \mathrm{~m}$ and 99.5 percentile meteorology is assumed in performing dose calculations. 99.5 percentile meteorology corresponds to wind speeds less than $1 \mathrm{~m} / \mathrm{s}$.

The aerosol resuspension release rate from the surface of the growing pool varies with time, as the release rate is proportional to the surface area of the pool. The time integrated dose over the 0 - to 12.5 hour time period can be estimated, however, by using the average resuspension release rate over the time period of interest. The average pool surface area is $1500 \mathrm{yd}^{2}$ (one 
WHC-SD-WM-CN-057, Rev. 0

half the final pool surface area). The resuspension release flux is converted to a volumetric basis using a waste density of $1.4 \mathrm{~kg} / \mathrm{L}$. This is the estimated density of waste slurry containing $1 / 3$ vol fraction solids. The volumetric resuspension flux is $1.4 \mathrm{E}-10 \mathrm{~L} / \mathrm{m}^{3}-\mathrm{s}(2 \mathrm{E}-10 / 1.4)$. therefore

The average resuspension release rate while the pool is growing is

$$
\begin{aligned}
Q^{\prime}(\text { res, pool }) & =\left(1.4 \mathrm{E}-10 \mathrm{~L} / \mathrm{m}^{2}-\mathrm{s}\right)\left(1500 \mathrm{yd} \mathrm{d}^{2}\right)(3 \mathrm{ft} / \mathrm{yd})^{2}(1 \mathrm{~m} / 3.28 \mathrm{ft})^{2} \\
= & 1.8 \mathrm{E}-7 \mathrm{~L} / \mathrm{s}
\end{aligned}
$$

Multiplying this average release rate by the time period the pool is growing gives the total release over this phase of the accident.

$$
Q(\text { res, pool })=(1.8 \mathrm{E}-7 \mathrm{~L} / \mathrm{s})(60 \mathrm{~s} / \mathrm{min})(750 \mathrm{~min})=8.1 \mathrm{E}-3 \mathrm{~L}
$$

\subsubsection{Resuspension Release from Contaminated Soil After Pool Soaks In}

A respirable release fraction of $8.4 \mathrm{E}-5$ over 24 hours is used to estimate the resuspension release after the transfer pump is shut off. This resuspension fraction comes from HDBK-3010-94, Section 3.2.4.4. This resuspension fraction is based on experiments with UNH solutions spilled on soil and dried under low wind speed conditions $(<2.5 \mathrm{mph})$. These experiments are reported in BNWL-1732 (1973). The data collected during the experiments indicate that the resuspension release is not constant over time. Most of the resuspendable particles can be expected to come off early. Figure 2-1 provides a graph showing measured resuspension rates with time. This graph is reproduced from BNWL-1732. Based on this graph, $50 \%$ of the release can be expected to occur in the first 2 hours after the waste soaks in and dries out. $80 \%$ can be expected to come off in the first 12 hours after soaking in. Ninety nine percent of the total release can be expected to occur within 16 hours after the waste soaks into the soil.

The release quantities, in equivalent $L$ of waste, over the various time periods of interest are calculated by multiplying the total leak volume by the appropriate respirable release fraction, correcting for the time varying nature of the release. The total release from the contaminated soil over a 24 hour time frame after soaking in (i.e., in the 12.5-h to 36.5-h time frame) is:

$$
Q(\text { res, soil, tot })=(37,500 \text { gal })(3.8 \mathrm{~L} / \mathrm{gal})(8.4 \mathrm{E}-5)=12 \mathrm{~L}
$$

The total release quantity is used in Section 3 to estimate the offsite receptor dose. The resuspension release is essentially over 28.5 hours after the leak breaks through the berm, because $99 \%$ of the dose occurs in the first 16 hours after the waste soaks into the ground (which occurs at $12.5 \mathrm{~h}$ ). Long term resuspension from contaminated soil can be expected to add insignificantly to the release estimated above. 


\section{WHC-SD-WM-CN-057, Rev. 0}

The onsite receptor can be exposed to resuspended particles for a $12 \mathrm{~h}$ duration (approximately 1 work shift). The release over the 12 hour time frame is $80 \%$ of the total release:

$$
\begin{aligned}
Q(\text { res, soil, } 12.5-\text { to } & 24.5-\mathrm{h}) \\
= & 9.6 \mathrm{~L}
\end{aligned}
$$

\subsubsection{Maximum Release Rate For Estimating Toxicological Exposures}

The toxicological consequences of the accident are determined based on the maximum release rate (see Section 3 ). Resuspension from the contaminated soil surface results in a larger release than resuspension of the surface of the liquid pool. The maximum resuspension release rate during the accident occurs in the 12.5 to $14.5 \mathrm{~h}$ time frame. During this 2-h time frame, half of the total soil resuspension volume occurs. The maximum resuspension release rate is:

$$
Q^{\prime}(\text { res, soil, } \max )=[(6 \mathrm{~L}) /(2 \mathrm{~h})](1 \mathrm{~h} / 3600 \mathrm{~s})=8.3 \mathrm{E}-4 \mathrm{~L} / \mathrm{s}
$$

\subsection{CONSEQUENCE ANALYSIS}

The onsite and offsite receptor receive an inhalation dose from resuspended aerosols and particulates. In accordance with the methodology outlined in SARR-037, the offsite receptor is assumed to be subject to a 24-h uptake ingestion dose in addition to the inhalation dose. The onsite receptor will receive significant external dose due to direct shine and skyshine. The shine and skyshine dose from the pool and contaminated soil will be negligible to the offsite receptor due to the extreme distance to that receptor. Both receptors can be effected by the chemicals and heavy metals in the release as well as by the radioactive components of the waste.

The following sections estimate the dose and toxicological effects to the onsite and offsite receptors.

\subsubsection{Onsite and Offsite Receptor Inhalation Dose Estimates}

The onsite and offsite receptor inhalation doses are calculated in accordance with the methodology outl ined in WHC-SD-WM-SARR-016 (1996) and WHCSD-WM-SARR-037 (1996). The inhalation doses are calculated using the following equation:

$$
D_{i n h}=(Q)\left(X / Q^{\prime}\right)(B R)\left(U L D_{i n h}\right)
$$

Where,

$$
\begin{aligned}
& D_{\text {inh }}=\text { dose, in } S v(50-y r \text { CEDE) } \\
& Q=\text { respirable release volume, in equivalent } L_{3} \text { of waste } \\
& X / Q^{\prime}=\text { atmospheric dispersion coeffiçient, in } \mathrm{s} / \mathrm{m}^{3} \\
& B R=\text { receptor breathing rate, in } \mathrm{m}^{3} / \mathrm{s}
\end{aligned}
$$




\section{WHC-SD-WM-CN-057, Rev. 0 \\ $U^{U L D_{i n h}}=$ inhalation unit liter dose, in Sv/L}

The respirable release volumes are determined in Section 2.3. The acute $X / Q$ 's for the onsite and offsite receptors from SARR-016 are reproduced in Table 23. The active man's breathing rate is $3 \cdot 3 \mathrm{E}-4 \mathrm{~m} / \mathrm{s}$. The inhalation ULDs for each tank waste type, by solids and liquids fractions, are reproduced from SARR-037 in Table 2-2.

The material released in this accident is SST waste with an estimated maximum solids content of $33 \mathrm{vol} \%$. The composite ULD ${ }_{\text {inh }}$ for the SST slurry is estimated by combining the SST ULDs for solids and inquids (from Table 2-2) in their appropriate volume ratios, as follows:

$$
\begin{aligned}
U_{L D}(\text { SST slurry }) & =(0.67)(1.1 \mathrm{ES} \mathrm{SV} / \mathrm{L})+(0.33)(2.2 \mathrm{E} 5 \mathrm{SV} / \mathrm{L}) \\
& =8.0 \mathrm{E} 4 \mathrm{~Sv} / \mathrm{L}
\end{aligned}
$$

2.4.1.1 Onsite Receptor Inhalation Dose. The total duration of the accident is $26.5 \mathrm{~h}$. The onsite receptor is assumed to be exposed for a duration of 12 hours (approximately 1 shift). The worst case release occurs in the 12 hours after the liquid pool soaks into the ground. From Section 2.3 .4 , the $12 \mathrm{~h}$ resuspension release from the contaminated soil is $9.6 \mathrm{~L}$. To simplify the calculation, the acute $X / Q^{\prime}$, with plume meander, from Table 2-3 is used. It is appropriate to apply plume meander because the release period exceeds 1 hour. The inhalation dose to the maximally exposed onsite receptor therefore is:

$$
\begin{aligned}
D(\text { on, inh }) & =(9.6 \mathrm{~L})\left(1.13 \mathrm{E}-2 \mathrm{~s} / \mathrm{m}^{3}\right)\left(3.3 \mathrm{E}-4 \mathrm{~m}^{3} / \mathrm{s}\right)(8.0 \mathrm{E} 4 \mathrm{SV} / \mathrm{L}) \\
& =2.9 \mathrm{SV}(290 \mathrm{rem})
\end{aligned}
$$

2.4.1.2 Offsite Receptor Inhalation Dose. The offsite receptor is exposed for the duration of the accident. This receptor receives an inhalation dose from aerosols resuspended from the surface of the pool while it is growing and in liquid form and an inhalation dose from resuspended contaminated soil after the pool soaks in. From Section 2.3.3, the release from the liquid pool is $8.1 \mathrm{E}-3 \mathrm{~L}$. From Section 2.3 .4 , the total release from contaminated soil is $12 \mathrm{~L}$. Using the acute offsite $X / Q^{\prime}$, with plume meander, the inhalation dose to the offsite receptor is:

$$
\begin{aligned}
D(\text { off, inh }) & =(8.1 \mathrm{E}-3 \mathrm{~L}+12 \mathrm{~L})\left(2.12 \mathrm{E}-5 \mathrm{~s} / \mathrm{m}^{3}\right)\left(3.3 \mathrm{E}-4 \mathrm{~m}^{3} / \mathrm{s}\right)(8.0 \mathrm{E} 4 \mathrm{SV} / \mathrm{L}) \\
& =6.7 \mathrm{E}-3 \mathrm{SV}(0.67 \mathrm{rem})
\end{aligned}
$$

\subsubsection{Offsite Receptor Ingestion Dose Estimate}

The offsite receptor is assumed to be exposed to a $24 \mathrm{~h}$ uptake ingestion dose as well as to an inhalation dose. This is in accordance with SARR-037. The dose effect due to ingestion is estimated with the following equation:

$$
D_{i n g}=(Q)\left(X / Q^{\prime}\right)\left(U L D_{i n g}\right)
$$

Where, 
WHC-SD-WM-CN-057, Rev. 0

$D_{\text {ing }}=24-h$ uptake ingestion dose, in Sv (50-yr CEDE)

$Q=$ respirable release volume, in equivalent $L$ of waste

$X / Q^{\circ}=$ atmospheric dispersion coefficient, in $\mathrm{s} / \mathrm{m}^{3}$

$U L_{\text {ing }}=$ inhalation unit liter dose, in $5 v-\mathrm{m}^{3} / \mathrm{s}-\mathrm{L}$

The material released in this accident is SST waste with an estimated maximum solids content of 33 vol \%. The composite ULD for the SST slurry is estimated by combining the SST ULDs for solids and ipquids (from Table 2-2) in their appropriate volume ratios, as follows:

$$
\begin{aligned}
U_{L} D_{\text {ing }}(\text { SST slurry }) & =(0.67)\left(0.052 \mathrm{~Sv}-\mathrm{m}^{3} / \mathrm{s}-\mathrm{L}\right)+(0.33)\left(4.1 \mathrm{~Sv}-\mathrm{m}^{3} / \mathrm{s}-\mathrm{L}\right) \\
& =1.4 \mathrm{~Sv}-\mathrm{m}^{3} / \mathrm{s}-\mathrm{L}
\end{aligned}
$$

This ULD ${ }_{\text {ing }}$ includes external exposure due to shine from particles deposited on the ground around the receptor. The offsite $X / Q$ and the total resuspension release volume are the same as used previously. The ingestion dose to the offsite receptor is:

$$
\begin{aligned}
D(\text { ing, off }) & =(8.1 \mathrm{E}-3 \mathrm{~L}+12 \mathrm{~L})\left(2.12 \mathrm{E}-5 \mathrm{~s} / \mathrm{m}^{3}\right)\left(1.4 \mathrm{~Sv}-\mathrm{m}^{3} / \mathrm{s}-\mathrm{L}\right) \\
& =3.6 \mathrm{E}-4 \mathrm{SV}(3.6 \mathrm{E}-2 \mathrm{rem})
\end{aligned}
$$

\subsubsection{Direct Shine Dose to Onsite Receptor}

The direct shine dose to the onsite receptor is estimated using the MICROSHEILD computer program (Grove 1992). WHC-SD-WM-SARR-016 (1996) contains a description of the calculational methods used in this codes. Two MICROSHEILD runs are performed. The first run is made to calculate the dose contribution from the important gamma emitters. The second run is made to calculate the dose contribution from bremsstrahlung radiation produced during the decay of $\mathrm{Sr}-90 / \mathrm{Y}-90$.

2.4.3.1 Shine Dose Due to Gamna Emitters. The onsite receptor receives the maximum inhalation dose during the 12 hours after the pool soaks into the ground. The direct shine dose is therefore calculated for the same time period.

2.4.3.1.1 MICROSHIELD Input. The shine dose at the receptor location is dependent on the source geometry, the location of the receptor with respect to the source volume, the activity of gamma emitters in the source volume, and the source and shield material characteristics and densities.

Source Geometry. As discussed previously the pool is postulated to assume a circular shape with a radius of $93 \mathrm{ft}(28 \mathrm{~m})$. The source volume is therefore modelled as a disk $28 \mathrm{~m}$ in diameter. The height of the disk (i.e., depth of penetration of waste into the soil) is given by the following equation:

$$
d=v /(p i)\left(r^{2}\right)(v)
$$




\section{WHC-SD-WM-CN-057, Rev. 0}

Where $d=$ depth of waste penetration into the soil, $V=$ volume of waste in circular size pool, pi $=3.14, r=$ radius, and $v=$ void volume of the soil. The void volume of Hanford soil is estimated to range from 0.3 to 0.4 . For this analysis, a void volume (porosity) of 0.4 is assumed. This is conservative because it results in the shallowest penetration of waste into the soil. Inserting the appropriate parameters gives:

$$
\begin{aligned}
d & =(37,500 \mathrm{gal})\left(1 \mathrm{ft}^{3} / 7.48 \mathrm{gal}\right) /\left[(3.14)(93 \mathrm{ft})^{2}(0.4)\right] \\
& =0.46 \mathrm{ft}=5.5 \mathrm{in}(14 \mathrm{~cm}) .
\end{aligned}
$$

Onsite Receptor Location. The onsite receptor is assumed to be $100 \mathrm{~m}$ from the site of the leak. The circular pool is assumed to form between the berm and the receptor. The receptor is therefore $72 \mathrm{~m}$ [100 - 28] from the center of the poot and $44 \mathrm{~m}[100-2(28)]$ from the leading edge of the pool. The dose rate is calculated for a point $1.5 \mathrm{~m}$ off the ground to determine effects to the trunk of the receptor.

Source Activities. The SST radionuclide inventories from Table 2-1 are used to define the gamma emitter activities in the source volume. For the composite SST material containing 33 vol \% solids, the following activities are estimated by multiplying the solids and 1 iquids concentrations by the appropriate volume fraction. The daughter $\mathrm{Ba}-137 \mathrm{~m}$ is in equilibrium with its parent Cs-137 at a 0.946 ratio. The source volume activities for the important gamma emitters are as follows:

$$
\begin{aligned}
& \text { Cs-137 activity }= {[(1.0 \mathrm{E} 11 \mathrm{~Bq} / \mathrm{L})(0.33)+2.2 \mathrm{E} 10 \mathrm{~Bq} / \mathrm{L}(0.67)] } \\
& \mathrm{X}(37,500 \mathrm{gal})(3.79 \mathrm{~L} / \mathrm{gal})=6.8 \mathrm{E} 15 \mathrm{~Bq} \\
& \mathrm{Ba}-137 \mathrm{~m} \text { activity }=(0.946)(\mathrm{Cs}-137 \text { activity })=6.4 \mathrm{E} 15 \mathrm{~Bq} \\
& \text { Eu-154 activity }= {[(5.8 \mathrm{Eg} \mathrm{Bq} / \mathrm{L})(0.33)+(2.4 \mathrm{Eg} \mathrm{Bq} / \mathrm{L})(0.67)] } \\
& \times(37,500 \mathrm{gal})(3.79 \mathrm{~L} / \mathrm{gal})=5.0 \mathrm{E} 14 \mathrm{~Bq} \\
& \text { Co-60 activity }= {[(4.2 \mathrm{E} 8 \mathrm{~Bq} / \mathrm{L})(0.33)+(9.5 \mathrm{E} 6 \mathrm{~Bq} / \mathrm{L})(0.67)] } \\
& \times(37,500 \mathrm{gal})(3.79 \mathrm{~L} / \mathrm{gal})=2.1 \mathrm{E} 13 \mathrm{~Bq}
\end{aligned}
$$

Shield Materials. The waste is modelled in the shine runs as water with a density of $1.4 \mathrm{~g} / \mathrm{cc}$ (the estimated density of a waste slurry containing 33 vol \% solids). Normalizing across the soil volume gives an overall waste density of $(0.4)(1.4 \mathrm{~g} / \mathrm{cc})=0.56 \mathrm{~g} / \mathrm{cc}$. The soil in the source volume is modelled as concrete with a density of $1.6 \mathrm{~g} / \mathrm{cc}$ (the estimated soil bulk density).

The soil between the edge of the pool and the receptor is modelled as a side clad shield consisting a concrete with an overall density of $1.6 \mathrm{~g} / \mathrm{cc}$ as in the source volume.

2.4.3.1.2 MICROSHIELD Results. The input and output file from the MICROSHIELD run are included in Appendix $C$, Case 1 . The cylindrical source 


\section{WHC-SD-WM-CN-057, Rev. 0}

was divided into 10 radial, 10 circumferential, and 10 axial kernels or segments.

The total exposure rate, with buildup, was found to be $275 \mathrm{mR} / \mathrm{h}$. Exposure in Roentgen is conservatively converted to effective dose equivalent, in rem, using a conversion factor of 1 . Multiplying the exposure rate by the exposure duration of $12 \mathrm{~h}$ gives a total shine dose, due to gamma emitters, of $3300 \mathrm{mrem}$, or $33 \mathrm{mSv}$.

2.4.3.2 Shine Dose Due to Bremsstrahlung Radiation. The shine dose due to brehmstrahlung radiation was estimated with MICROSHIELD using the same geometries and shield material densities used to estimate the direct shine dose.

Appendix D includes output generated by BREMCALC (Rittman 1992) of the photon production rates for $1 \mathrm{Ci}(3.7 \mathrm{E} 10 \mathrm{~Bq})$ of $\mathrm{Sr}-90 / \mathrm{Y}-90$, in both water and concrete. The source term in this scenario is made up of a mixture of concrete (to simulate soil) and water. It is conservative to use the photon production rate values for concrete since they are higher than those of water.

The photon production rates in the source pool can be estimated by scaling up the photon production rates for concrete in Appendix $D$ by the total activity of $\mathrm{Sr}-90 / \mathrm{Y}-90$ in the source volume. From Table $2-1$, the activity concentration of Sr-90/Y-90 in the solids phase of SST waste is $1.6 \mathrm{E} 12 \mathrm{~Bq} / \mathrm{L}$. In the liquids phase of SST waste, the Sr-90/Y-90 concentration is $1.1 \mathrm{E} 10$ $\mathrm{Bq} / \mathrm{L}$. Multiplying by the appropriate solids and liquids fractions and the total spill quantity gives the total activity of $5 r-90 / \gamma-90$ in the source volume:

$$
\begin{aligned}
\text { Sr-90/Y-90 Activity } & =[(1.6 \mathrm{E} 12 \mathrm{~Bq} / \mathrm{L})(0.33)+(1.1 \mathrm{E} 10 \mathrm{~Bq} / \mathrm{L})(0.67)] \\
& =\times(37,500 \mathrm{gal})(3.79 \mathrm{~L} / \mathrm{gal}) \\
& =7.6 \mathrm{E} 16 \mathrm{~Bq}(2.05 \mathrm{E} 6 \mathrm{Ci})
\end{aligned}
$$

To estimate the photon production rate of the contaminated soil, the photon production rates for concrete, from Appendix $D$, were scaled up by a factor of $2.05 E+06$. The photon production rates entered into the code, for each of the energies bins of concern, are summarized in Table 2-4.

The MICROSHIELD output file is contained in Appendix C, Case 2. From the output file, the estimated exposure rate is $40.3 \mathrm{mR} / \mathrm{h}$, with buildup in air. Over a $12 \mathrm{~h}$ time period, the total dose (EDE) is approximately $480 \mathrm{mrem}$, or $4.8 \mathrm{mSv}$.

\subsubsection{Skyshine Dose to Onsite Receptor}

The skyshine dose from the contaminated soil is estimated using the MICROSKYSHINE computer code (1987). WHC-SD-WM-SARR-016 contains a description of the calculational methods used in this code. Again, the dose due to gamma emitters and brehmsstrahlung effect are calculated separately. 
2.4.4.1 Skyshine Dose Due to Gamma Emitters. The source volume geometry, receptor location, gamma emitter activities, and shield material densities are the same as in the direct shine calculations. In the MICROSKYSHINE input, a hypothetical shield wall is inserted between the source volume and the receptor that is just tall enough to preclude line of sight radiation to the receptor.

The geometrical parameters that must be entered into the MICROSKYSHINE code are depicted in Figure 2-2. For this analysis, the shield wall was arbitrarily located $1 \mathrm{~m}$ from the edge of the pool (the location of the wall is not important as long as it precludes line of sight radiation but is not too high to mask skyshine). For this analysis, $W=28 \mathrm{~m}$ (section 2.3 .1$), R=28+$ $1=29 \mathrm{~m}, X=100-W-R=71 \mathrm{~m}$, and $L=14.5 \mathrm{~cm}$ (Section 2.4.3.1.1). The dose is modelled at a point $1.5 \mathrm{~m}$ off the ground (Section 2.4.3.1.1). Therefore, $-H=1.5-Y$. The parameter $Y$ was determined using similar triangles, with the following equation:

$$
Y /(W+R)=-1.5 /(W+R+X)
$$

Rearranging and solving gives $Y=0.855 \mathrm{~m}$ and $\mathrm{H}=-0.645 \mathrm{~m}$.

The results of the SKYSHINE run are included in Appendix $E$ as Case 1. The estimated exposure rate is $1.31 \mathrm{R} / \mathrm{h}$. Multiplying by the $12 \mathrm{~h}$ exposure duration and converting to absorbed dose, using a conservative conversion factor of 1 ( $R$ to $r e m)$, gives a total dose of 16 rem (160 mSv).

2.4.4.2 Skyshine Dose Due to Bremsstrahlung Radiation. The skyshine dose due to brehmsstrahiung radiation is measured using the same geometrical parameters as in the previous section. The photon production rates and energy groups entered into the code are the same as those used for the direct shine doses in Section 2.4.3.3.

The output file from the MICROSKYSHINE run are included in Appendix $\mathrm{E}$ as Case 2. The estimated exposure rate is $0.39 \mathrm{R} / \mathrm{h}$. Multiplying by the $12 \mathrm{~h}$ exposure period, using a conservative conversion factor of $l$ ( $R$ to rem), gives a total dose of 4.7 rem (47 mSv).

\subsubsection{Summary of Dose Estimates, by Pathway}

Table 2-5 provides a summary of the onsite and offsite dose estimates, by pathway, for the unmitigated accident scenario. The shine and skyshine dose estimates in the table are the combined total from gamma emitters and brehmsstrahlung radiation. The total dose to the onsite receptor due to the inhalation, shine, and skyshine pathways is $3100 \mathrm{mSv}$ (310 rem). The total dose to the offsite receptor from the inhalation and ingestion pathways is 7.1E-3 Sv (0.71 rem).

\subsubsection{Toxicological Exposure Estimates for the Onsite and Offsite Receptors}


Onsite and offsite toxicological exposures are assessed using the sumof-fractions methodology outlined in WHC-CM-SARR-011 (1996). Table 2-6 gives the unit liter sum-of-fractions multipliers for the various waste types, broken into liquids values and solids values. Toxicological exposure is assessed by multiplying the release rate by the appropriate sum-of-fractions multiplier from Table 2-6. (Note that the sum-of-fraction multipliers are dependent on accident frequency). Products less than one are considered to indicate acceptable risk (i.e., indicate exposures below evaluation guidelines).

The sum of fractions multipliers for SST waste containing 33 vol \% solids is estimated by combining the SST solids and liquids values from Table 2-6. For the Anticipated frequency range, the sum of the fraction multiplier for the onsite receptor is $2.0 \mathrm{~s} 4 \mathrm{~s} / \mathrm{L}[(0.33)(4.0 \mathrm{E} 4 \mathrm{~s} / \mathrm{L})+(0.67)(1.0 \mathrm{E} 4)]$. For the offsite receptor and the Anticipated frequency category, the sum of the fraction multiplier for SST waste containing 33 vol \% solids is $36 \mathrm{~s} / \mathrm{L}$ $[(0.33)(94)+(0.67)(8)]$.

Toxicological exposures are assessed using the maximum release rate. From Section 2.3.5, the maximum release rate of waste during the unmitigated accident is $8.3 E-4 \mathrm{~L} / \mathrm{s}$. The onsite and offsite sum of fractions results are therefore:

Onsite sum of fractions $=(8.3 \mathrm{E}-4 \mathrm{~L} / \mathrm{s})(2.0 \mathrm{E} 4 \mathrm{~s} / \mathrm{L})=16.7$

Offsite sum of fractions $=(8.3 \mathrm{E}-4 \mathrm{~L} / \mathrm{s})(36 \mathrm{~s} / \mathrm{L})=3.0 \mathrm{E}-2$ 
WHC-SD-WM-CN-057, Rev. 0

\subsection{MITIGATED ACCIDENT ANALYSIS}

\subsection{SCENARIO}

In the mitigated scenario, operator action is credited with limiting the duration of the release and limiting the volume of waste material spilled. The unencased bermed lines that may be used for interim stabilization of SSTs are of relatively short length. It is feasible to have operators or radiation protection technicians survey these lines every 30 minutes during SST transfers to detect pipe failures and berm washouts. With radiation monitors it is likely the leak can be detected before the berm washes out.

For this analysis it is assumed that the leak occurs and washes out the berm shortly after the operator passes. Flow continues for 30 minutes until the operator passes by that point at the next surveillance interval. It is al so assumed that it takes 30 minutes for the appropriate transfer pump to be shutdown following detection of the leak. It is al so assumed that emergency response procedures will be implemented to evacuate workers in the vicinity of the leak to upwind staging areas within 30 minutes of detection of the leak. It is assumed that radiation surveys will be performed to establish a safe distance around the leak site and that access controls will be implemented to minimize onsite worker exposures. A human factors analysis will be performed as part of the FSAR effort to verify that the transfer pump can be shutoff and emergency response procedures implemented within the 30 minute time period.

The leak occurs at the maximum flowrate of $50 \mathrm{gpm}$ for $1 \mathrm{~h}$, releasing 3000 gal of waste. Line holdup is al so assumed to flow through the leakage path. During the first hour while the pump is running aerosols are released from the growing liquid pool. After the pump is shutoff, it is conservatively assumed, for modelling purposes, that the waste instantaneously soaks into the ground. The onsite receptor is exposed to resuspended aerosols from the growing liquid pool for one hour before being evacuated to an upwind staging area. In addition, the onsite receptor is exposed to direct shine and skyshine radiation from the growing pool for a $1 \mathrm{~h}$ time period. The offsite receptor is exposed to resuspended aerosols from the growing liquid pool for one hour and to resuspended particulates from the contaminated ground for an additional 24 hours. No credit is taken for emergency response to cover up the leak to minimize resuspension within the $24 \mathrm{~h}$ period.

\subsection{FREQUENCY CATEGORY}

The frequency category for the mitigated accident scenario is Anticipated, the same as in the unmitigated scenario, as no credit is taken for controls to reduce the likelihood of the accident.

\subsection{SOURCE TERM DEVELOPMENT}

\subsubsection{Final Surface Pool Volume and Dimensions}


WHC-SD-WM-CN-057, Rev. 0

As in the unmitigated analysis, it is conservatively assumed that the leak is catastrophic, with $100 \%$ of pipe flow leaking onto the soil surface. The amount of waste required to saturate the berm, resulting in washout, is conservatively neglected. At the maximum flowrate of $50 \mathrm{gpm}$, the total flow over the $1 \mathrm{~h}$ time frame required for detection of the leak and shut off of the pump is $3000 \mathrm{gal}$ [ $(50 \mathrm{gpm})(60 \mathrm{~min})]$. It is conservatively assumed that the leak occurs at the low point of the bermed pipe and that the entire line holdup drains back through the leakage path during the 1 hour time frame required to shutoff the pump. It is assumed that the transfer is made through a 3 in schedule 40 pipe that is $1000 \mathrm{ft}$ long. This gives a conservative estimate for line holdup. The inner diameter of a 3 in schedule 40 pipe is $3.068 \mathrm{in}$. The volume of liquid waste that can drain back through this line is given by the following equation:

$$
V(\text { drainback })=(p i)(d)^{2} L / 4
$$

Where, $p i=3.14, d=$ diameter of the pipe, $L=$ length of the pipe. Solving gives:

$$
V(\text { drainback })=(3.14)(3.068 / 12 \mathrm{ft})^{2}(1000 \mathrm{ft}) / 4=51.3 \mathrm{ft}^{3}
$$

The drainback in gallons is $384\left[\left(51.3 \mathrm{ft}^{3}\right)\left(7.48 \mathrm{gal} / \mathrm{ft}^{3}\right)\right]$.

The total volume spilled is less than $3400 \mathrm{gal}$. It is assumed that the waste forms a circular shape with an average waste depth of 1 in. This assumed pool depth is judged to be conservative because some of the waste would be expected to soak in reducing the spread of the waste, and the unevenness of Hanford terrain makes average pool depths less than 1 in unlikely. The surface area covered by the pool can be calculated by dividing the pool volume by the average depth. The gives a surface area of:

$$
A=(3400 \mathrm{gal})\left(1 \mathrm{ft}^{3} / 7.48 \mathrm{gal}\right) /(1 / 12 \mathrm{ft})=5450 \mathrm{ft}^{2}
$$

The radius of the pool is given by:

$$
r=\left[5450 \mathrm{ft}^{2} /(\mathrm{pi})\right]^{1 / 2}=41.7 \mathrm{ft}=12.7 \mathrm{~m}
$$

\subsubsection{Resuspension Release from Growing Liquid Pool}

A resuspension mass flux of $2 \mathrm{E}-10 \mathrm{~kg} / \mathrm{m}^{2}-\mathrm{s}$ is used to estimate the release from the liquid pool while the pump is running. This is the same resuspension flux as used in the unmitigated analysis in Section 2.3.3. Converting to a volumetric basis using a waste density of $1.4 \mathrm{~kg} / \mathrm{L}$ gives a resuspension flux of $1.4 \mathrm{E}-10 \mathrm{~L} / \mathrm{m}^{2}-\mathrm{s}\left[\left(2 \mathrm{E}-10 \mathrm{~kg} / \mathrm{m}^{2}-\mathrm{s}\right) /(1.4 \mathrm{~kg} / \mathrm{L})\right]$. The resuspension release rate varies with time. The total resuspension release volume over the first hour of the accident is estimated based on the average surface area of the pool over that time frame. The average surface area is $5450 \mathrm{ft}^{2} / 2=2725 \mathrm{ft}^{2}=830 \mathrm{~m}^{2}$. Multipiying the volumetric resuspension fiux by the average surface area gives the average resuspension rate of the first hour of the accident: 
WHC-SD-WM-CN-057, Rev. 0

$Q^{\prime}($ res, pool $)=\left(1.4 \mathrm{E}-10 \mathrm{~L} / \mathrm{m}^{2}-\mathrm{s}\right)\left(830 \mathrm{~m}^{2}\right)=1.2 \mathrm{E}-7 \mathrm{~L} / \mathrm{s}$

Multiplying by the release duration gives the total release volume.

$Q($ res, pool $)=(1.16 \mathrm{E}-7 \mathrm{~L} / \mathrm{s})(1 \mathrm{~h})(3600 \mathrm{~s} / \mathrm{h})=4.2 \mathrm{E}-4 \mathrm{~L}$

\subsubsection{Resuspension Release from Contaminated Ground After Pool Soaks In}

As in Section 2.3.4, a resuspension respirable fraction of 8.4E-5 over 24 hours is used to estimate the release from the pool after it soaks into the ground. Multiplying by the total release volume gives:

$$
Q(\text { res, soil })=(3400 \text { gal })(3.79 \mathrm{~L} / \text { gal })(8.4 \mathrm{E}-5)=1.1 \mathrm{~L}
$$

\subsubsection{Maximum Release Rate for Estimating Toxicological Exposures}

For the offsite receptor, the maximum release rate occurs after the waste soaks into the soil and dries out. Based on the discussion in Section 2.3.4, $50 \%$ of the total release above could be expected to occur over a two hour time frame. This gives a maximum release rate for the offsite receptor of $1.5 \mathrm{E}-4 \mathrm{~L} / \mathrm{s}[(1.1 \mathrm{~L} / 2 \mathrm{~h})(1 \mathrm{~h} / 3600 \mathrm{~s})]$.

During the hour the onsite receptor is exposed the release exists as a pool. Although some of the pool may soak into the ground while the pump is running, the ground will remain damp. The ground is not expected to dry out giving a release rate as high as estimated above for the offsite receptor. The maximum release rate for the onsite receptor (over the first hour of the accident) is $1.2 \mathrm{E}-7 \mathrm{~L} / \mathrm{s}$ (Section 3.3.2).

\subsection{CONSEQUENCE ANALYSIS}

The receptor exposure pathways are the same as in the unmitigated analysis, Section 2.4 .

\subsubsection{Onsite and Offsite Receptor Inhalation Dose Estimates}

3.4.1.1 Onsite Receptor Inhalation Dose. This receptor is exposed only during the first hour of the accident. The receptor is evacuated after 1 hour. The resuspension release volume during this period is $4.2 \mathrm{E}-4 \mathrm{~L}$. Over this short time period, it is necessary to use the acute $X / Q^{\prime}$, without plume meander. From Table $x$, this $X / Q^{\prime}$ is $3.41 \mathrm{E}-2 \mathrm{~s} / \mathrm{m}^{3}$. Using the 'SST composite siurry ULD $\mathrm{D}_{\text {inh }}$ developed earlier, and the active receptor breathing rate of $3.3 \mathrm{E}-4 \mathrm{~m}^{3} / \mathrm{s}$, the dose to the onsite receptor is:

$$
\begin{aligned}
D(\text { on, inh })= & (4.2 \mathrm{E}-4 \mathrm{~L})\left(3.41 \mathrm{E}-2 \mathrm{~s} / \mathrm{m}^{3}\right)\left(3.3 \mathrm{E}-4 \mathrm{~m}^{3} / \mathrm{s}\right)(8.0 \mathrm{E} 4 \mathrm{~Sv} / \mathrm{L}) \\
= & 3.8 \mathrm{E}-4 \mathrm{~Sv}(3.8 \mathrm{E}-2 \mathrm{rem})
\end{aligned}
$$


3.4.1.1 offsite Receptor Inhalation Dose. The offsite receptor receives inhalation dose due to resuspension off the liquid pool for 1 hour and due to resuspension off the contaminated soil surface for an additional 24 hours. Using the acute offsite $X / Q^{\prime}$ (with plume meander since the release is long term) from Table 2-3, the offsite receptor dose is:

$$
\begin{aligned}
\mathrm{D}(\mathrm{off}, \mathrm{inh}) & =(4.2 \mathrm{E}-4 \mathrm{~L}+1.1 \mathrm{~L})\left(2.12 \mathrm{E}-5 \mathrm{~s} / \mathrm{m}^{3}\right)\left(3.3 \mathrm{E}-4 \mathrm{~m}^{3} / \mathrm{s}\right)(8.0 \mathrm{E} 4 \mathrm{sV} / \mathrm{L}) \\
= & 6.2 \mathrm{E}-4 \mathrm{SV}(6.2 \mathrm{E}-2 \mathrm{rem})
\end{aligned}
$$

\subsubsection{Offsite Receptor Ingestion Dose Estimate}

From Section 2.4.2, ULD ${ }_{\text {ing }}$ (SST slurry) $=1.4 \mathrm{~Sv}-\mathrm{m}^{3} / \mathrm{s}-\mathrm{L}$. The dose to the offsite receptor due to $24-h$ uptake of his own fruits and vegetables is:

$$
\begin{aligned}
\mathrm{D} \text { (off, ing) } & =(4.2 \mathrm{E}-4 \mathrm{~L}+1.1 \mathrm{~L})\left(2.12 \mathrm{E}-5 \mathrm{~s} / \mathrm{m}^{3}\right)\left(1.4 \mathrm{sv}-\mathrm{m}^{3} / \mathrm{s}-\mathrm{L}\right) \\
= & 3.3 \mathrm{E}-5 \mathrm{SV}(3.3 \mathrm{E}-3 \mathrm{rem})
\end{aligned}
$$

\subsubsection{Estimate of Direct Shine Dose to the Onsite Receptor}

The dose rate to the onsite receptor will vary considerably over the receptor's $1 \mathrm{~h}$ exposure duration, because the pool dimensions and activity change over the course of the hour. The shine dose to the onsite receptor is conservatively estimated based on the maximum dose rate for the fully formed pool, when the edge of the pool is closest to the receptor and the pool activity is maximized. As in the unmitigated analysis, the pool is postulated to be located between the berm and the receptor. The pool is postulated to assume a circular shape as it grows. The onsite receptor is located $100 \mathrm{~m}$ from the location on the berm where the leak occurs.

The shine doses due to gamma and bremsstrahlung radiation are estimated using the MICROSHIELD computer code, as in unmitigated accident analysis (Section 2.4.3). The dose rate is estimated for a surface pool 1 in deep (i.e., no soaking in). The pool is modelled as a disk. In this case, the maximum pool size is 3400 gal spread out over a surface area of $5450 \mathrm{ft}^{2}$. The radius of the disk is $12.7 \mathrm{~m}$ (Section 3.3.1). To estimate self shielding effects, the waste pool is modelled as water with a density of $1.4 \mathrm{~g} / \mathrm{cc}$. For the direct shine dose estimate, the soil between the pool and the receptor is modelled as a side $\mathrm{clad}$ shield of concrete with a density of $1.6 \mathrm{~g} / \mathrm{cc}$. The source volume activities for the important gamma emitters are estimated from the inventories reported in Table 2-1, as follows, for entry into the code:

$$
\begin{aligned}
& \text { Cs-137 activity }=[(1.0 \mathrm{E} 11 \mathrm{~Bq} / \mathrm{L})(0.33)+2.2 \mathrm{E} 10 \mathrm{~Bq} / \mathrm{L}(0.67)] \\
& x(3400 \mathrm{gal})(3.79 \mathrm{~L} / \mathrm{ga})=6.2 \mathrm{E} 14 \mathrm{~Bq} \\
& \mathrm{Ba}-137 \mathrm{~m} \text { activity }=(0.946)(\mathrm{Cs}-137 \text { activity })=5.8 \mathrm{E} 14 \mathrm{~Bq} \\
& \text { Eu-154 activity }=[(5.8 \mathrm{Eg} \mathrm{Bq} / \mathrm{L})(0.33)+(2.4 \mathrm{Eg} \mathrm{Bq} / \mathrm{L})(0.67)] \\
& \mathrm{x}(3400 \mathrm{gal})(3.79 \mathrm{~L} / \mathrm{gal})=4.5 \mathrm{E} 13 \mathrm{~Bq} \\
& \text { Co-60 activity }=[(4.2 \mathrm{E} 8 \mathrm{~Bq} / \mathrm{L})(0.33)+(9.5 \mathrm{E} 6 \mathrm{~Bq} / \mathrm{L})(0.67)]
\end{aligned}
$$




\section{WHC-SD-WM-CN-057, Rev. 0 \\ $\times(3400 \mathrm{gal})(3.79 \mathrm{~L} / \mathrm{gal})=1.9 \mathrm{E} 12 \mathrm{~Bq}$}

For estimating the dose due to bremsstrahlung radiation, the $5 r-90 / Y-90$ source volume activity is estimated in a similar manner:

$$
\begin{aligned}
\text { Sr-90/Y-90 Activity } & =[(1.6 \mathrm{E} 12 \mathrm{~Bq} / \mathrm{L})(0.33)+(1.1 \mathrm{E} 10 \mathrm{~Bq} / \mathrm{L})(0.67)] \\
& =x(3400 \mathrm{gal})(3.79 \mathrm{~L} / \mathrm{gal}) \\
& =6.9 \mathrm{E} 15 \mathrm{~Bq}(1.86 \mathrm{E} \mathrm{Ci})
\end{aligned}
$$

To estimate the photon production rate of the surface pool due to bremsstrahlung effect, the photon production rates for concrete, from the BREMCALC results in Appendix $\mathrm{D}$, were scaled up by a factor of $1.86 \mathrm{E}+06$. Using the concrete photon production rates is conservative for the liquid pool. The photon production rates entered into the code are summarized in Table 3-1.

The output files from the MICROSHIELD runs are included in Appendix $C$ as Cases 3 and 4 . The output files summarize the input parameters as well as the results of the code calculations. From the output file shown as Case 3 , the maximum dose rate due to direct gamma radiation is $88 \mathrm{mR} / \mathrm{h}$, with buildup. From the output file shown as case 4, the maximum exposure rate, in air, due to bremsstrahlung radiation is $13 \mathrm{mR} / \mathrm{h}$. Multiplying the maximum dose rate by the exposure duration of $1 \mathrm{~h}$ gives a conservative estimate of the integrated exposure to the onsite receptor. The exposure rate in Roentgen is converted to effective dose equivalent, in rem, using a conservative conversion factor of 1:

$D($ on, shine, gamma radiation $)=(88 \mathrm{mR} / \mathrm{h})(1 \mathrm{~h})=88$ mrem $(8.8 \mathrm{E}-01 \mathrm{mSv})$

$D($ on, shine, bremsstrahlung $)=(13 \mathrm{mR} / \mathrm{h})(1 \mathrm{~h})=13 \mathrm{mrem}(13 \mathrm{E}-01 \mathrm{mSv})$

\subsubsection{Estimate of Skyshine Dose to the Onsite Receptor}

As in the unmitigated accident analysis, the MICROSKYSHINE code was used to estimate to dose to the onsite receptor due to gamma radiation and bremsstrahlung radiation.

The source volume geometry, receptor location with respect to the source volume, gamma emitter activities, photon production rates (for estimating bremsstrahlung skyshine) and shield material densities are the same as in the direct shine calculations. The geometrical parameters required by the MICROSKYSHINE code are depicted in Figures 2-2. For this analysis, the shield wall was arbitrarily located $1 \mathrm{~m}$ from the edge of the pool (the location of the wall is not important as long as it precludes line of sight radiation but is not too high to mask skyshine). For this analysis, $W=12.7$ $\mathrm{m}$ (section 3.3.1), R1 = 12.7 $+1=13.7 \mathrm{~m}, \mathrm{X}=100-\mathrm{W}-\mathrm{R} 1=73.6 \mathrm{~m}$, and $\mathrm{L}=$ $2.54 \mathrm{~cm}$ (Section 3.3.1). The dose is modelled at a point $1.5 \mathrm{~m}$ off the ground. Therefore, $-H=1.5-Y$. The parameter $Y$ was determined using similar triangles, with the following equation:

$$
Y /(W+R 1)=-1.5 /(W+R 1+X)
$$


WHC-SD-WM-CN-057, Rev. 0

Rearranging and solving gives $Y=0.396 \mathrm{~m}$ and $H=-1.10 \mathrm{~m}$.

The results of the MICROSKYSHINE runs are included in Appendix $E$ as Cases 3 and 4 . The estimated exposure rate from gamma emitters was found to be $220 \mathrm{mR} / \mathrm{h}$. The estimated dose rate from bremsstrahlung was found to be 65 $\mathrm{mR} / \mathrm{h}$. Multiplying by the onsite exposure duration of 1 hour, and converting to effective dose equivalent using a conversion factor of 1 , gives the following dose estimates:

$D($ on, skyshine, gamma radiation $)=(220 \mathrm{mR} / \mathrm{h})(1 \mathrm{~h})=220 \mathrm{mrem}(2.2 \mathrm{mSv})$

$D$ (on, skyshine, bremsstrahlung) $=(65 \mathrm{mR} / \mathrm{h})(1 \mathrm{~h})=65 \mathrm{mrem}(0.65 \mathrm{mSv})$

These dose estimates are conservative because they are based on the maximum exposure rate for the fully formed pool.

\subsubsection{Summary of Mitigated Radiological Dose Estimates, by Pathway}

Table 3-2 provides a summary of the onsite and offsite dose estimates, by pathway, for the unmitigated accident scenario. The total dose to the onsite receptor due to the inhalation, shine, and skyshine pathways is $4.4 \mathrm{mSv}$ $(0.44 \mathrm{rem})$. The total dose to the offsite receptor from the inhalation and ingestion pathways is $0.65 \mathrm{mSv}(6.5 \mathrm{E}-02 \mathrm{rem})$.

\subsubsection{Toxicological Exposure Estimates for the Onsite and Offsite Receptors}

From Section 3.3.4, the maximum release rate for the onsite receptor (during the first hour of the accident) is $1.2 \mathrm{E}-7 \mathrm{~L} / \mathrm{s}$. The maximum release for the offsite receptor is $1.5 \mathrm{E}-4 \mathrm{~L} / \mathrm{s}$. From Section 2.4.6, onsite sum of fractions multiplier for the anticipated frequency category is $2.0 E 4 \mathrm{~s} / \mathrm{L}$. The offsite sum of fractions multiplier for the anticipated frequency category is $36 \mathrm{~s} / \mathrm{L}$. The onsite and offsite sum of fractions results are therefore:

$$
\begin{aligned}
& \text { Onsite sum of fractions }=(1.2 \mathrm{E}-7 \mathrm{~L} / \mathrm{s})(2.0 \mathrm{E} 4 \mathrm{~s} / \mathrm{L})=2.4 \mathrm{E}-3 \\
& \text { Offsite sum of fractions }=(1.5 \mathrm{E}-4 \mathrm{~L} / \mathrm{s})(36 \mathrm{~s} / \mathrm{L})=5.4 \mathrm{E}-3
\end{aligned}
$$




\subsection{COMPARISON TO EVALUATION GUIDELINES}

Table 4-1 summarizes the results of the consequence analyses above and compares the consequences with the TWRS evaluation guidelines. Table 4-1 shows that the unmitigated accident produces onsite and offsite dose consequences in excess of the evaluation guideline for the Anticipated frequency category (the frequency category of the accident). The unmitigated onsite toxicological consequences are also shown to be above the evaluation guideline.

Table 4-1 shows that the controls selected to mitigate the consequences of the accident are sufficient to keep onsite and offsite radiological and toxicological exposures below the evaluation guidelines for the Anticipated frequency category. 
WHC-SD-WW-CN-057, Rev. 0

\subsection{SUMMARY OF KEY ASSUMPTIONS}

This section summarizes the key parameters and assumptions used in the above unmitigated and mitigated accident analyses. The 1 ist of key parameters and assumptions define the safety envelope of the analyses and will be useful for future USQ determinations.

\subsection{KEY ASSUMPTIONS, UNMITIGATED ACCIDENT ANALYSIS}

In the unmitigated accident analysis, the representative case analyzed is a leak from an unencased bermed line during an SST transfer which utilizes a submersible pump (as opposed to a saltwe11 pump). The key assumptions in the analysis are as follows:

- The waste leaked is assumed to be SST waste, as defined in WHC-SD-WMSARR-037 (1996), containing 33 vol \% entrained solids.

- The leak is assumed to cause a washout of the berm due to "piping" phenomena.

- The leak is assumed to be catastrophic, with $100 \%$ of pipe flow after berm washout assumed to be available to from a surface pool.

- The leak is assumed to occur at the maximum submersible pump flowrate of $50 \mathrm{gpm}$.

- The surface pool is assumed to ultimately cover a soil surface area of $3000 \mathrm{yd}^{2}$, based on the above mentioned raw water leak.

- The transfer pump is assumed to be shut off after 37,500 gal of waste has leaked to the soil surface (see Section 2.3.1 for basis), approximately 12.5 hours after the leak is initiated.

- After the transfer pump is shut off, the waste is assumed to soak into the soil, leaving entrained and dissolved salts as surface contamination.

- The maximally exposed onsite receptor is assumed to be exposed to particles resuspended from the contaminated soil surface, after the waste has soaked in, for a period of 12 hours (1 work shift with overtime).

- The maximally exposed onsite receptor is assumed to be exposed to shine and skyshine from the contaminated soil, after the waste has soaked in, for a period of 12 hours.

- The maximally exposed offsite receptor is assumed to be exposed to resuspended waste from the surface of the growing liquid pool for the first $\mathbf{1 2 . 5}$ hours of the accident and to waste particles resuspended from the contaminated soil for an additional 24 hours. 
- For calculating shine and skyshine doses to the onsite receptor, the surface pool is assumed to be circular, located between the berm and the receptor.

- For calculating shine and skyshine doses, the onsite receptor is assumed to $100 \mathrm{~m}$ from the site of the leak $(100 \mathrm{~m}$ from the far edge of the circular pool).

- For calculating shine and skyshine doses to the onsite receptor, the waste is assumed to soak in to the soil to an average depth of 5.5 in, based on a soil porosity of 0.4 . The waste is assumed to occupy the void spaces in the soil.

- For calculating shine and skyshine doses to the onsite receptor, the soil is assumed to have shielding properties similar to concrete with a density of $1.6 \mathrm{~g} / \mathrm{cc}$.

- For calculating shine and skyshine doses to the onsite receptor, the waste is assumed to have self shielding properties similar to water with a density of $1.4 \mathrm{~g} / \mathrm{cc}$.

- Shine and skyshine doses to the offsite receptor are assumed to be negligible due to distance.

\subsection{KEY ASSUMPTIONS, MITIGATED ACCIDENT ANALYSIS}

The mitigated scenario credits operator surveillances performed every 30 minutes with detecting the leak. Credit is also taken for emergency response actions to evacuate the onsite receptor to an upwind staging area at a safe distance within 30 minutes of detection of the leak. The key assumptions used in the mitigated analysis are summarized as follows:

- The leak is assumed to occur in an unencased bermed transfer line during an SST transfer using a submersible transfer pump.

- The waste leaked is assumed to be SST waste, as defined in WHC-SD-WMSARR-037 (1996), containing 33 vol \% entrained solids.

- The leak is assumed to washout the berm due to "piping" phenomena.

- The leak is assumed to occur at the maximum submersible pump flowrate of $50 \mathrm{gpm}$.

- The leak is assumed to be catastrophic, with $100 \%$ of pipe flow after berm washout available to form surface pool.

Berm washout is assumed to occur shortly after an operator surveillance. 
WHC-SD-WM-CN-057, Rev. 0

- The leak is assumed to continue undetected until the next operator surveillance 30 minutes later.

- $\quad 30$ minutes is assumed for operator action to turn off the appropriate transfer pump and to evacuate the onsite receptor to a safe distance upwind.

- $\quad 400 \mathrm{gal}$ of 1 ine holdup is assumed to drain back through the leakage path after the transfer pump is shut off.

- The waste is assumed to form a liquid pool on the surface for a period of 1 hour until the transfer pump is shut off.

- The surface pool is assumed to soak into the ground after the transfer pump is shut off.

- The onsite receptor is assumed to be exposed to resuspended material from the surface of the growing liquid waste pool for a period of 1 hour. The onsite receptors exposure after 1 hour is assumed to be negligible due to emergency response.

- The onsite receptor is assumed to be exposed to shine and skyshine from the growing liquid pool for a period of 1 hour.

- The maximum offsite receptor is assumed to be exposed to resuspended aerosols from the pool surface for 1 hour and to resuspended particulates from the contaminated soil for an additional 24 hours after the waste soaks into the ground.

- For calculating shine and skyshine doses to the onsite receptor, the surface pool is assumed to be circular, located between the berm and the receptor.

- For calculating shine and skyshine doses to the onsite receptor, the pool is assumed to spread to an average thickness of $l$ in.

- For calculating shine and skyshine doses, the onsite receptor is assumed to $100 \mathrm{~m}$ from the site of the leak $(100 \mathrm{~m}$ from the far edge of the circular pool).

- For calculating shine and skyshine doses to the onsite receptor, the waste is assumed to have self shielding properties similar to water with a density of $1.4 \mathrm{~g} / \mathrm{cc}$.

- For calculating shine and skyshine doses to the onsite receptor, the soil between the pool and the receptor is assumed to have immersion shielding properties similar to concrete with a density of $1.6 \mathrm{~g} / \mathrm{cc}$.

- Shine and skyshine doses to the offsite receptor are assumed to be negligible due to distance. 
WHC-SD-WM-CN-057, Rev. 0

\subsection{PEER REVIEW}

Appendix $F$ contains the signed off peer review checklist for this document. 
WHC-SD-WM-CN-057, Rev. 0

\subsection{REFERENCES}

ARH-2977 RD, 1974, Report On the Cleanup Activities Following the 241-S Tank Farm Contamination 0ccurrence at the Hanford Reservation, Richland, Washington on November 14, 1973, At lantic Richfield Hanford Company, Richland, Washington.

DOE-HDBK-3010-94, 1994, Airborne Release Fractions/Rates and Respirable Fractions for Nonreactor Nuclear Facilities, U.S. Department of Energy, Washington, D.C.

Grove, 1987, MICROSKYSHINE, Grove Engineering, Inc., 15125 Shady Grove Road, Rockville, Maryland.

Grove, 1992, MICROSHIELD Version 4, Grove Engineering, Inc., 15125 Shady Grove Road, Rockville, Maryland.

Rittman, P. D., 1992, BREMCALC - A Computer Program for Calculating Electron and Positron Bremsstrahlung, WHC-SA-1435-FP, Westinghouse Hanford Company, Richl and, Washington.

WHC-SD-WM-SAR-034, 1989, Safety Analysis Report, Stabilization of Single-Shell Waste Storage Tanks by Salt Well Jet Pumping, Rev. 0, Westinghouse Hanford Company, Richland, Washington.

WHC-SD-WM-SARR-011, 1996, Toxicological Chemical Considerations for Tank Farm Releases, Rev. 2, Westinghouse Hanford Company, Richland, Washington.

WHC-SD-WM-SARR-016, 1996, Tank Waste Compositions and Atmospheric Dispersion Coefficients for Use in Accelerated Safety Analysis Consequence Assessments, Rev. 2, Westinghouse Hanford Company, Richland, Washington.

WHC-SD-WM-SARR-037, 1996, Development of Radiological Concentrations and Unit Liter Doses for TWRS FSAR Radiological Consequence Calculations, Rev. 0, Westinghouse Hanford Company, Richland, Washington. 
WHC-SD-WM-CN-057, Rev. 0

Figure 2-1. Graph of Resuspension Fraction Vs. Time

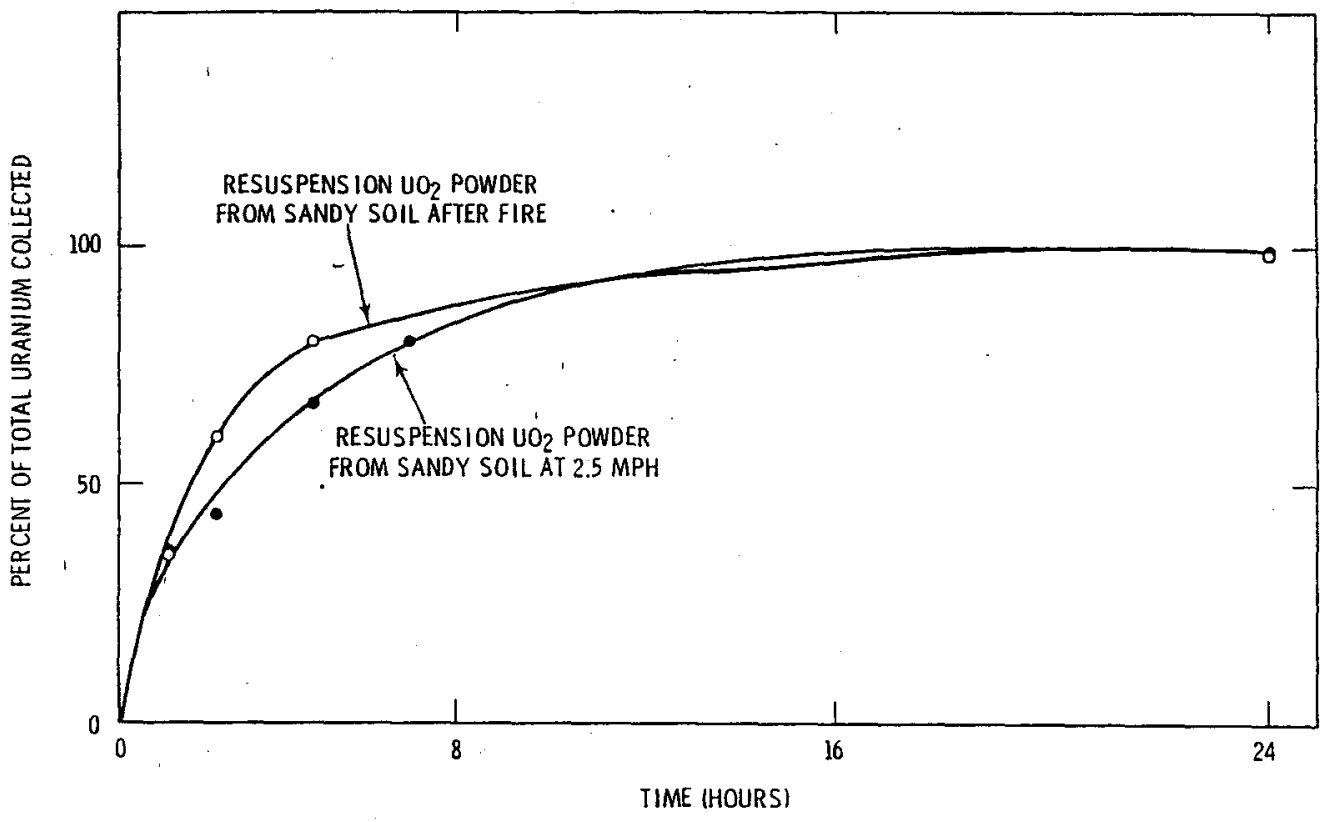

AERODYNAMIC ENTRAINMENT OF URANIUM DIOXIDE POWDER FROM SMOOTH, SANDY SOIL AT AN AIR VELOCITY OF 2.5 MPII -

- From Figure 14 of BNWL-1732

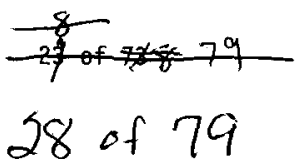


WHC-SD-WM-CN-057, Rev. 0

Figure 2-2. Geometrical Parameters for MICROSKYSHINE Calculations

Top View

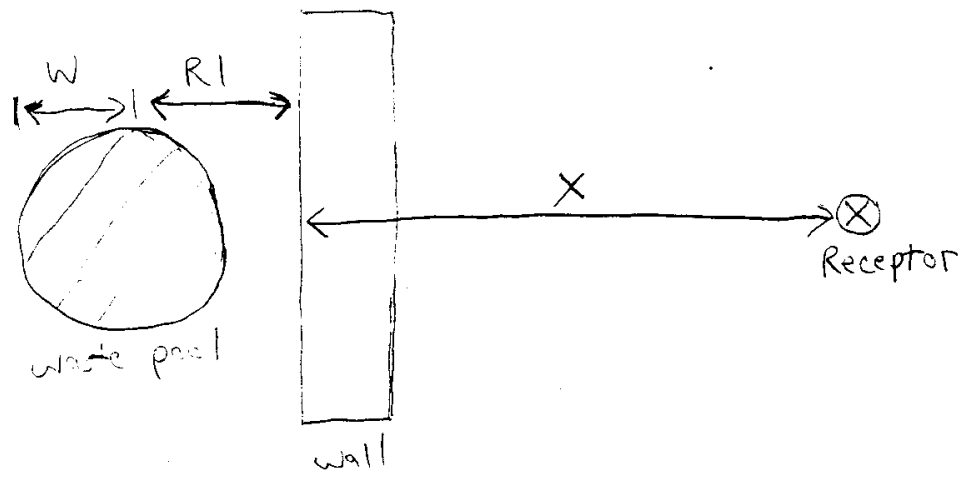

Side View
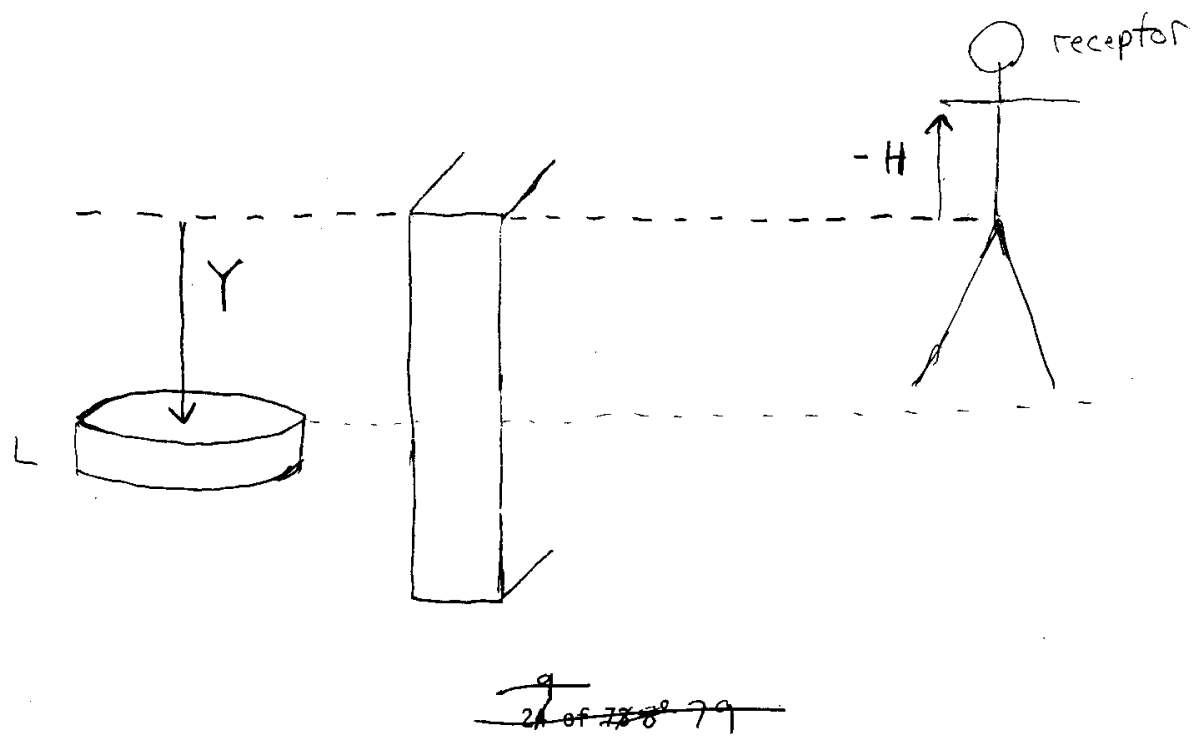

59 of 79 
WHC-SD-WM-CN-057, Rev. 0

Table 2-1 Bounding Activity Concentrations, by Waste Type*

\begin{tabular}{|c|c|c|c|c|c|c|}
\hline \multirow[b]{2}{*}{ Isotope } & \multicolumn{6}{|c|}{ Concentration $(\mathrm{Bq} / \mathrm{L})$} \\
\hline & $\begin{array}{l}\text { SST } \\
\text { Liquids }\end{array}$ & $\begin{array}{l}\text { SST } \\
\text { Solids }\end{array}$ & $\begin{array}{l}\text { DST } \\
\text { Liquids }\end{array}$ & $\begin{array}{l}\text { DST } \\
\text { Solids }\end{array}$ & $\begin{array}{l}\text { Aging } \\
\text { Waste } \\
\text { Liquids }\end{array}$ & $\begin{array}{l}\text { Aging } \\
\text { Waste } \\
\text { Solids }\end{array}$ \\
\hline${ }^{60} \mathrm{Co}$ & $9.53 \mathrm{E}+06$ & $4.2 \quad \mathrm{E}+08$ & $6.97 \quad \mathrm{E}+06$ & $1.5 \mathrm{E}+07$ & $7.71 \quad \mathrm{E}+05$ & $4.9 \quad E+08$ \\
\hline${ }^{90} \mathrm{Sr}$ & $1.05 \mathrm{E}+10$ & $1.6 \mathrm{E}+12$ & $4.59 \quad E+09$ & $5.2 \mathrm{E}+10$ & $5.60 \quad E+09$ & $2.9 \mathrm{E}+12$ \\
\hline${ }^{90} \mathrm{Y}$ & $1.05 \mathrm{E}+10$ & $1.6 \mathrm{E}+12$ & $4.59 \quad E+09$ & $5.2 \mathrm{E}+10$ & $5.60 \quad E+09$ & $2.9 \quad E+12$ \\
\hline${ }^{137} \mathrm{Cs}$ & $2.21 E+10$ & $1.0 \quad E+11$ & $5.86 \mathrm{E}+10$ & $5.9 \mathrm{E}+10$ & $8.84 \mathrm{E}+10$ & $9.8 E+10$ \\
\hline${ }^{154} \mathrm{Eu}$ & $2.35 \mathrm{E}+09$ & $5.8 \quad E+09$ & $4.18 \quad E+07$ & $3.0 \mathrm{E}+08$ & 0.00 & 0.00 \\
\hline${ }^{237} \mathrm{~Np}$ & 0.00 & 0.00 & $2.3 \mathrm{E}+05$ & $8.1 E+05$ & $9.20 \mathrm{E}+04$ & $9.9 E+08$ \\
\hline${ }^{238} \mathrm{Pu}$ & $9.21 \quad E+04$ & $1.9 \quad \mathrm{E}+08$ & $1.78 \quad E+06$ & $7.2 \quad E+07$ & $2.75 \mathrm{E}+03$ & $6.7 \quad E+07$ \\
\hline${ }^{239} \mathrm{Pu}$ & $3.62 \quad \mathrm{E}+07$ & $4.4 \quad E+08$ & $7.65 \mathrm{E}+06$ & $1.6 \quad E+09$ & $1.20 \mathrm{E}+06$ & $4.4 E+08$ \\
\hline${ }^{241} \mathrm{Pu}$ & $2.57 \quad E+08$ & $3.2 \quad \mathrm{E}+09$ & $1.84 \quad E+07$ & $3.8 \quad E+09$ & $3.39 \mathrm{E}+05$ & $1.7 \quad E+09$ \\
\hline${ }^{241} \mathrm{Am}$ & $4.23 \quad E+07$ & $2.3 \quad \mathrm{E}+08$ & $3.40 \quad E+07$ & $2.7 \quad E+09$ & $1.10 \mathrm{E}+06$ & $1.1 \mathrm{E}+10$ \\
\hline${ }^{244} \mathrm{~cm}$ & $4.23 E+05$ & $2.3 \mathrm{E}+06$ & $1.22 \mathrm{E}+05$ & $1.6 \mathrm{E}+07$ & $1.10 \mathrm{E}+04$ & $6.1 E+07$ \\
\hline
\end{tabular}

*From WHC-SD-WM-SARR-037 (1996) 
WHC-SD-WM-CN-057, Rev. 0

Table 2-2. Unit Liter Doses for Inhalation and Ingestion.

\begin{tabular}{|l|c|c|}
\hline \multicolumn{1}{|c|}{ Composite } & $\begin{array}{c}\text { Inhalation } \\
\text { ULD } \\
(\mathrm{SV} / \mathrm{L})\end{array}$ & $\begin{array}{c}\text { Ingestion ULD } \\
\left(\mathrm{SV}-\mathrm{m}^{3} / \mathrm{s}-\mathrm{L}\right)\end{array}$ \\
\hline $\begin{array}{l}\text { Single-shell tank } \\
\text { liquids }\end{array}$ & $1.1 \mathrm{E}+04$ & 0.052 \\
\hline $\begin{array}{l}\text { Single-shell tank } \\
\text { solids }\end{array}$ & $2.2 \mathrm{E}+05$ & 4.1 \\
\hline $\begin{array}{l}\text { Double-shell tank } \\
\text { liquids }\end{array}$ & $6.1 \mathrm{E}+03$ & 0.068 \\
\hline $\begin{array}{l}\text { Double-shell tank } \\
\text { solids }\end{array}$ & $5.3 \mathrm{E}+05$ & 0.48 \\
\hline $\begin{array}{l}\text { Aging waste facility } \\
\text { liquids }\end{array}$ & $1.4 \mathrm{E}+03$ & 0.092 \\
\hline $\begin{array}{l}\text { Aging waste facility } \\
\text { solids }\end{array}$ & $1.7 \mathrm{E}+06$ & 8.1 \\
\hline
\end{tabular}

NOTE: The information in this table is from WHC-SD-WM-SARR-037, 1996, Development of Radiological Concentrations and Unit Liter Doses for TWRS FSAR Radiological Consequence Calculations, West inghouse Hanford Company, Richland, Washington. ULD $=$ unit liter dose. 
Table 2-3. Centerline Atmospheric Dispersion Coefficients for 200-Area Tank Farm Acute, Ground Level Release

\begin{tabular}{|c|c|c|c|}
\hline $\begin{array}{c}\text { Maximum } \\
\text { individual }\end{array}$ & $\begin{array}{c}\text { Bounding } \\
\text { integrated } \\
x / Q \\
\left(s / \mathrm{m}^{3}\right)\end{array}$ & $\begin{array}{c}\text { Bounding } \\
\text { integrated } \\
\chi / Q^{\prime}\left(\mathrm{s} / \mathrm{m}^{3}\right) \\
\text { with plume } \\
\text { meander }\end{array}$ & $\begin{array}{c}\text { Maximum } \\
\text { puff } x / Q \\
\left(1 / \mathrm{m}^{3}\right)\end{array}$ \\
\hline $\begin{array}{l}\text { Onsite } \\
\text { sector and } \\
\text { distance }\end{array}$ & $\begin{array}{c}3.41 \mathrm{E}-02 \\
\mathrm{E} 100 \mathrm{~m}\end{array}$ & $\begin{array}{l}1.13 \quad \mathrm{E}-02 \\
\operatorname{ESE} 100 \mathrm{~m}\end{array}$ & $\begin{array}{c}9.85 \mathrm{E}-03 \\
\mathrm{E} 100 \mathrm{~m}\end{array}$ \\
\hline $\begin{array}{l}\text { Offsite } \\
\text { sector and } \\
\text { distance }\end{array}$ & $\begin{array}{c}2.83 \quad E-5 \\
N \quad 8,760 \mathrm{~m}\end{array}$ & $\begin{array}{l}2.12 \mathrm{E}-05 \\
\mathrm{~N} 8,760 \mathrm{~m}\end{array}$ & $\begin{array}{c}1.14 \text { E-7 } \\
\text { NNW } 8,690 \\
m\end{array}$ \\
\hline
\end{tabular}

NOTE: The information in this table is from WHC-SD-WM-SARR-016, 1996, Tank Waste Compositions and Atmospheric Dispersion Coefficients for Use in Accelerated Safety Analys is Consequence Assessments, Westinghouse Hanford Company, Richland, Washington.

$E=$ east

ESE $=$ east, southeast.

$N=$ north

NWW $=$ north north west 
WHC-SD-WM-CN-057, Rev. 0

Table 2-4. Photon production Rates Entered in the MICROsHIELD and MICROsRYshINE Codes, Unmitigated Accident Analysis

\begin{tabular}{|c|c|c|}
\hline $\begin{array}{l}\text { Group Midpoint } \\
\text { Energy (MeV) }\end{array}$ & $\begin{array}{l}\text { Photon Production } \\
\text { Rate for } 1 \text { Ci Sr-90 } \\
\text { in Concrete } \\
\text { (photons/s) }\end{array}$ & $\begin{array}{l}\text { Photon Production } \\
\text { Rate Entered into } \\
\text { Code for } 2.05 \mathrm{E} 6 \mathrm{Ci} \\
\text { of Sr-90 (photons/s) }\end{array}$ \\
\hline 0.015 & $1.24 \mathrm{E}+09$ & $2.54 \mathrm{E}+15$ \\
\hline 0.025 & $6.26 \mathrm{E}+08$ & $1.28 \mathrm{E}+15$ \\
\hline 0.035 & $3.99 \mathrm{E}+08$ & $8.18 \mathrm{E}+14$ \\
\hline 0.045 & $2.83 E+08$ & $5.80 \mathrm{E}+14$ \\
\hline 0.055 & $2.14 \mathrm{E}+08$ & $4.39 \mathrm{E}+14$ \\
\hline 0.065 & $1.69 \mathrm{E}+08$ & $3.46 E+14$ \\
\hline 0.075 & 1. $37 \mathrm{E}+08$ & $2.81 \mathrm{E}+14$ \\
\hline 0.085 & $1.14 \mathrm{E}+08$ & $2.34 \mathrm{E}+14$ \\
\hline 0.095 & $9.61 E+07$ & $1.97 E+14$ \\
\hline 0.150 & $5.03 E+08$ & $1.03 \mathrm{E}+15$ \\
\hline 0.250 & $1.95 \mathrm{E}+08$ & $4.0 E+14$ \\
\hline 0.350 & $9.98 \mathrm{E}+07$ & $2.05 \mathrm{E}+14$ \\
\hline 0.475 & $7.84 \mathrm{E}+07$ & $1.61 \mathrm{E}+14$ \\
\hline 0.650 & $4.89 E+07$ & $1.00 \mathrm{E}+14$ \\
\hline 0.825 & $1.82 \mathrm{E}+07$ & $3.73 E+13$ \\
\hline 1.000 & $1.28 \mathrm{E}+07$ & $2.62 \mathrm{E}+13$ \\
\hline 1.225 & $6.95 \mathrm{E}+06$ & $1.42 \mathrm{E}+13$ \\
\hline 1.475 & $2.46 \mathrm{E}+06$ & $5.04 \mathrm{E}+12$ \\
\hline 1.700 & $6.12 E+05$ & 1. $25 \mathrm{E}+12$ \\
\hline 1.900 & $1.51 \mathrm{E}+05$ & 3. $10 \mathrm{E}+11$ \\
\hline 2.1 & $1.59 \mathrm{E}+04$ & $3.26 \mathrm{E}+10$ \\
\hline 2.3 & $8.51 \mathrm{E}+01$ & $1.74 \mathrm{E}+08$ \\
\hline
\end{tabular}


WHC-SD-WM-CN-057, Rev. 0

Table 2-5. Summary of Unmitigated Dose Estimates, by Pathway

\begin{tabular}{|c|c|c|}
\hline Pathway & Onsite Receptor & Offsite Receptor \\
\hline Inhalation & $2900 \mathrm{mSV}(290 \mathrm{rem})$ & $6.7 \mathrm{mSv}(0.67 \mathrm{rem})$ \\
\hline Ingestion & NA & $\begin{array}{l}0.36 \mathrm{mSv}(3.6 \mathrm{E}-2 \\
\text { rem) }\end{array}$ \\
\hline Shine, gamma & $33 \mathrm{mSv}$ (3.3 rem) & negligible \\
\hline $\begin{array}{l}\text { Shine, } \\
\text { bremsstrahlung }\end{array}$ & $4.8 \mathrm{mSv}(0.48 \mathrm{rem})$ & negligible \\
\hline skyshine, gamma & $160 \mathrm{mSv}$ (16 rem) & negligible \\
\hline $\begin{array}{l}\text { Skyshine, } \\
\text { bremsstrahlung }\end{array}$ & $47 \mathrm{mSv}$ ( $4.7 \mathrm{rem})$ & negligible \\
\hline Total Dose & $3100 \mathrm{mSv}(310 \mathrm{rem})$ & $7.1 \mathrm{mSv}(0.71 \mathrm{rem})$ \\
\hline
\end{tabular}


Table 2-6. sum-of-Fraction of Risk Guidelines for a Unit Release of Chemicals and Gases.

*The sum of fractions are multiplied by the release rate for continuous release and release amount for a puff releases. Release rates for continuous releases are in units of liters per second for liquids and solids, and $\mathrm{m}^{3} / \mathrm{s}$ for gases. Puff release quantities are in units of liters for solids and liquids and $\mathrm{m}^{3}$ for gases.

\begin{tabular}{|c|c|c|c|c|}
\hline \multirow{2}{*}{$\begin{array}{c}\text { Tank waste type } \\
\text { (Units of sum of } \\
\text { fractions follow tank } \\
\text { waste type) }\end{array}$} & \multirow{2}{*}{$\begin{array}{l}\text { Maximum } \\
\text { individu } \\
\quad \text { al }\end{array}$} & \multicolumn{3}{|c|}{ Accident frequency, $1 / y r$} \\
\hline & & $1-10^{-2}$ & $\begin{array}{c}10^{-2}- \\
10^{-4}\end{array}$ & $10^{-4}-10^{-6}$ \\
\hline \multicolumn{5}{|c|}{ DST or SST solid or liquid continuous release } \\
\hline $\begin{array}{l}\text { Single-shell } \\
\text { liquids (s/L) }\end{array}$ & Onsite & $9.6 \mathrm{E}+03$ & $7.5 \mathrm{E}+02$ & $2.0 \mathrm{E}+02$ \\
\hline $\begin{array}{l}\text { Single-shell } \\
\text { liquids (s/L) }\end{array}$ & Offsite & $8.0 \mathrm{E}+00$ & $8.0 \mathrm{E}+00$ & $6.2 \mathrm{E}-01$ \\
\hline $\begin{array}{l}\text { Single-shell } \\
\text { solids (s/L) }\end{array}$ & Onsite & $4.0 \quad \mathrm{E}+04$ & $2.1 \mathrm{E}+04$ & $1.0 \mathrm{E}+03$ \\
\hline $\begin{array}{l}\text { Single-shell } \\
\text { solids (s/L) }\end{array}$ & Offsite & $9.4 \mathrm{E}+01$ & $3.3 \mathrm{E}+01$ & $1.7 \mathrm{E}+01$ \\
\hline $\begin{array}{l}\text { Double-shell } \\
\text { liquids (s/L) }\end{array}$ & Onsite & $1.0 \mathrm{E}+04$ & $7.5 \mathrm{E}+02$ & $2.1 \mathrm{E}+02$ \\
\hline $\begin{array}{l}\text { Double-shell } \\
\text { liquids (s/L) }\end{array}$ & Offsite & $8.4 \mathrm{E}+00$ & $8.4 \mathrm{E}+00$ & $6.2 \quad E-01$ \\
\hline $\begin{array}{l}\text { Double-shell solids } \\
\text { (s/L) }\end{array}$ & Onsite & $1.8 \mathrm{E}+04$ & $3.3 \mathrm{E}+03$ & $6.3 \mathrm{E}+02$ \\
\hline $\begin{array}{l}\text { Double-shell } \\
\text { solids (s/L) }\end{array}$ & Offsite & $1.9 \mathrm{E}+02$ & $1.5 \mathrm{E}+01$ & $2.8 \mathrm{E}+00$ \\
\hline \multicolumn{5}{|c|}{ DST or SST liquid or solid puff release } \\
\hline $\begin{array}{l}\text { Single-shell liquids } \\
\left(\mathrm{L}^{-1}\right)\end{array}$ & Onsite & $2.8 \mathrm{E}+03$ & $2.2 \mathrm{E}+02$ & $5.7 \mathrm{E}+01$ \\
\hline $\begin{array}{l}\text { Single-shell liquids } \\
\left(\mathrm{L}^{-1}\right)\end{array}$ & Offsite & $3.2 \mathrm{E}-02$ & $3.2 \mathrm{E}-02$ & $2.5 \mathrm{E}-03$ \\
\hline $\begin{array}{l}\text { single-shell solids } \\
\left(L^{-1}\right)\end{array}$ & Onsite & $1.2 \mathrm{E}+04$ & $6.0 \mathrm{E}+03$ & $2.9 \mathrm{E}+02$ \\
\hline $\begin{array}{l}\text { Single-shell solids } \\
\left(L^{-1}\right)\end{array}$ & Offsite & $3.8 \mathrm{E}-01$ & $1.3 \mathrm{E}-01$ & $6.9 \mathrm{E}-02$ \\
\hline $\begin{array}{l}\text { Double-shell liquids } \\
\left(\mathrm{L}^{-1}\right)\end{array}$ & Onsite & $2.9 \mathrm{E}+03$ & $2.2 \mathrm{E}+02$ & $6.0 \quad E+01$ \\
\hline
\end{tabular}


WHC-SD-WM-CN-057, Rev. 0

Table 2-6. Sum-of-Fraction of Risk Guidelines for a Unit Release of Chemicals and Gases.

*The sum of fractions are multiplied by the release rate for continuous release and release amount for a puff releases. Release rates for continuous releases are in units of liters per second for liquids and solids, and $\mathrm{m}^{3} / \mathrm{s}$ for gases. Puff release quantities are in units of liters for solids and liquids and $\mathrm{m}^{3}$ for gases.

\begin{tabular}{|c|c|c|c|c|}
\hline \multirow{2}{*}{$\begin{array}{c}\text { Tank waste type } \\
\text { (Units of sum of } \\
\text { fractions follow tank } \\
\text { waste type) }\end{array}$} & \multirow{2}{*}{$\begin{array}{l}\text { Maximum } \\
\text { individu } \\
\quad \text { al }\end{array}$} & \multicolumn{3}{|c|}{ Accident frequency, $1 / \mathrm{yr}$} \\
\hline & & $1-10^{-2}$ & $10^{-2}-$ & $10^{-4}-10^{-6}$ \\
\hline $\begin{array}{l}\text { Double-shell liquids } \\
\left(\mathrm{L}^{-1}\right)\end{array}$ & Offsite & $3.4 \quad E-02$ & $3.4 \mathrm{E}-02$ & $2.5 \mathrm{E}-03$ \\
\hline $\begin{array}{l}\text { Double-shell solids } \\
\left(\mathrm{L}^{-1}\right)\end{array}$ & Onsite & $5.2 \mathrm{E}+03$ & $9.7 \mathrm{E}+02$ & $1.8 \mathrm{E}+02$ \\
\hline $\begin{array}{l}\text { Double-shell solids } \\
\left(L^{-1}\right)\end{array}$ & Onsite & 7.7 E-01 & 5.9 E-02 & $1.1 \mathrm{E}-02$ \\
\hline
\end{tabular}


Table 3-1. Photon Production Rates Entered in MICROSHIELD and MICROSKYSHINE, Mitigated Accident Analysis

\begin{tabular}{||l|l|l||}
\hline \hline $\begin{array}{l}\text { Group Midpoint } \\
\text { Energy (MeV) }\end{array}$ & $\begin{array}{l}\text { Photon Production } \\
\text { Rate for 1 Ci Sr-90 } \\
\text { in Concrete } \\
\text { (photons/s) }\end{array}$ & $\begin{array}{l}\text { Photon Production } \\
\text { Rate Entered into } \\
\text { Code for 1.865 Ci } \\
\text { of Sr-90 (photons/s) }\end{array}$ \\
\hline 0.015 & $1.24 \mathrm{E}+09$ & $2.30 \mathrm{E}+14$ \\
\hline 0.025 & $6.26 \mathrm{E}+08$ & $1.16 \mathrm{E}+14$ \\
\hline 0.035 & $3.99 \mathrm{E}+08$ & $7.42 \mathrm{E}+13$ \\
\hline 0.045 & $2.83 \mathrm{E}+08$ & $5.26 \mathrm{E}+13$ \\
\hline 0.055 & $2.14 \mathrm{E}+08$ & $3.98 \mathrm{E}+13$ \\
\hline 0.065 & $1.69 \mathrm{E}+08$ & $3.14 \mathrm{E}+13$ \\
\hline 0.075 & $1.37 \mathrm{E}+08$ & $2.54 \mathrm{E}+13$ \\
\hline 0.085 & $1.14 \mathrm{E}+08$ & $2.12 \mathrm{E}+13$ \\
\hline 0.095 & $9.61 \mathrm{E}+07$ & $1.79 \mathrm{E}+13$ \\
\hline 0.150 & $5.03 \mathrm{E}+08$ & $9.36 \mathrm{E}+13$ \\
\hline 0.250 & $1.95 \mathrm{E}+08$ & $3.63 \mathrm{E}+13$ \\
\hline 0.350 & $9.98 \mathrm{E}+07$ & $1.46 \mathrm{E}+13$ \\
\hline 0.475 & $7.84 \mathrm{E}+07$ & $9.10 \mathrm{E}+12$ \\
\hline 0.650 & $4.89 \mathrm{E}+07$ & $9.10 \mathrm{E}+12$ \\
\hline 0.825 & $1.82 \mathrm{E}+07$ & $3.39 \mathrm{E}+12$ \\
\hline 1.000 & $1.28 \mathrm{E}+07$ & $2.38 \mathrm{E}+12$ \\
\hline 1.225 & $6.95 \mathrm{E}+06$ & $1.29 \mathrm{E}+12$ \\
\hline 1.475 & $2.46 \mathrm{E}+06$ & $4.58 \mathrm{E}+11$ \\
\hline 1.700 & $6.12 \mathrm{E}+05$ & $1.14 \mathrm{E}+11$ \\
\hline 1.900 & $1.51 \mathrm{E}+05$ & $2.81 \mathrm{E}+10$ \\
\hline 2.1 & $1.59 \mathrm{E}+04$ & $2.96 \mathrm{E}+09$ \\
\hline 2.3 & $8.51 \mathrm{E}+01$ & $1.58 \mathrm{E}+07$ \\
\hline
\end{tabular}


WHC-SD-WM-CN-057, Rev. 0

Table 3-2. summary of Mitigated Dose Estimates, by Pathway

\begin{tabular}{||l|l|l||}
\hline Pathway & Onsite Receptor & Offsite Receptor \\
\hline Inhalation & $\begin{array}{l}0.38 \mathrm{mSV} \\
(3.8 \mathrm{E}-02 \mathrm{rem})\end{array}$ & $\begin{array}{l}0.62 \mathrm{mSV} \\
(6.2 \mathrm{E}-02 \mathrm{mrem})\end{array}$ \\
\hline Ingestion & NA & $\begin{array}{l}3.3 \mathrm{E}-02 \mathrm{mSV} \\
(3.3 \mathrm{E}-03 \mathrm{rem})\end{array}$ \\
\hline Shine, gamma & $\begin{array}{l}0.88 \mathrm{mSV} \\
(8.8 \mathrm{E}-02 \mathrm{rem})\end{array}$ & negligible \\
\hline $\begin{array}{l}\text { Shine, } \\
\text { bremsstrahlung }\end{array}$ & $\begin{array}{l}0.13 \mathrm{mSv} \\
(1.3 \mathrm{E}-02 \mathrm{rem})\end{array}$ & negligible \\
\hline $\begin{array}{l}\text { Skyshine, gamma } \\
(0.2 \mathrm{mSv} \mathrm{rem})\end{array}$ & negligible \\
\hline $\begin{array}{l}\text { Skyshine, } \\
\text { bremsstrahlung }\end{array}$ & $\begin{array}{l}0.65 \mathrm{mSv} \\
(6.5 \mathrm{E}-02 \mathrm{rem})\end{array}$ & $\begin{array}{l}0.65 \mathrm{mSv} \\
(6.5 \mathrm{E}-02 \mathrm{rem})\end{array}$ \\
\hline Total Dose & $\begin{array}{l}4.2 \mathrm{mSv} \\
(0.42 \mathrm{rem})\end{array}$ & \\
\hline
\end{tabular}

Table 4-1. Consequences of subsurface Leak Resulting in Pool, Compared to Evaluation Guidelines

\begin{tabular}{|c|c|c|c|c|c|}
\hline \multirow[t]{2}{*}{ Receptor/hazard } & \multicolumn{2}{|c|}{ Calculated Dose/Exposure } & \multicolumn{3}{|c|}{ Evaluation quidel ine } \\
\hline & Unmit igated & Mitigated & Antictpoted & Unlikely & $\begin{array}{l}\text { Extremely } \\
\text { Unlikely }\end{array}$ \\
\hline Offsite/radiological & $7.1 \mathrm{msv}$ & $0.65 \mathrm{msv}$ & $1 \mathrm{msv}$ & $5 \mathrm{mSv}$ & $40 \mathrm{mSv}$ \\
\hline Onsite/radiological & $3100 \mathrm{msv}$ & $4.2 \mathrm{mSv}$ & S nsv. & $50 \mathrm{mSv}$ & $100 \mathrm{msv}$ \\
\hline $\begin{array}{l}\text { offsite/toxicological } \\
\text { sum-of-fractions }\end{array}$ & $3.0 \mathrm{E}-2$ & $5.4 \mathrm{E}-3$ & 1 & 1 & 1 \\
\hline $\begin{array}{l}\text { Onsite/toxicological } \\
\text { sum-of-fractions }\end{array}$ & 16.7 & $2.4 \mathrm{E}-3$ & 1 & 1 & 1 \\
\hline
\end{tabular}


WHC-SD-WM-CN-057, Rev. 0

APPENDICES

39 of 79 
WHC-SD-WM-CN-057, Rev, 0

\begin{abstract}
APPENDIX A
Historical subsurface Leaks from Tank Farm Transfer Iines
\end{abstract}

40 af 79 
WHC-SD-WM-CN-057, Rev. 0

Historical Subsurface Leaks from Tank Farm Transfer Lines

\begin{tabular}{|c|c|c|c|}
\hline $\begin{array}{l}\text { Occurrence } \\
\text { Number }\end{array}$ & Date & Leak Type & Description \\
\hline $73-45$ & $7 / 05 / 73$ & $\begin{array}{l}\text { Subsurface } \\
\text { leak }\end{array}$ & $\begin{array}{l}\text { Backhoe ran over and broke } \\
\text { a flange on a below grade } \\
\text { riser on a transfer line } \\
\text { at } T \text { tank farm. Watery } \\
\text { liquid was seen seeping } \\
\text { from the ground. Cause: } \\
\text { pipe flanges on transfer } \\
\text { lines at } T \text { farm were not } \\
\text { adequately marked. }\end{array}$ \\
\hline $75-145$ & $12 / 19 / 75$ & $\begin{array}{l}\text { Subsurface } \\
\text { leak }\end{array}$ & $\begin{array}{l}\text { Possible transfer piping } \\
\text { leakage during transfer } \\
\text { from Tank 103-B to Tank } \\
\text { l10-sx. Cause unknown. } \\
\text { Material balance } \\
\text { discrepancy was not } \\
\text { resolved. }\end{array}$ \\
\hline $79-61$ & $5 / 25 / 79$ & $\begin{array}{l}\text { Subsurface } \\
\text { leak }\end{array}$ & $\begin{array}{l}\text { slurry line SL-113 leaked } \\
\text { in } 241-5 \text { farm when being } \\
\text { readied for a pressure } \\
\text { test. cause: mechanical } \\
\text { failure of } 2 \text { inch carbon } \\
\text { steel line. }\end{array}$ \\
\hline $\begin{array}{l}\text { ROR-80- } \\
2788\end{array}$ & $11 / 11 / 80$ & $\begin{array}{l}\text { Subsurface } \\
\text { leak } \\
\text { forming } \\
\text { surface } \\
\text { pool }\end{array}$ & $\begin{array}{l}\text { Radioactive leak at east } \\
\text { side of } 242-5 \text { evaporator. } \\
\text { Direct buried (unencased) } \\
\text { line failed due to } \\
\text { galvanic corrosion. } 2000 \\
\text { gal of slurry were } \\
\text { spilled. } 200 \text { gal pool } \\
\text { formed at the surface. }\end{array}$ \\
\hline $\begin{array}{l}\text { WHC- } \\
\text { TANKFARM- } \\
\text { 1992-09 }\end{array}$ & $5 / 05 / 92$ & $\begin{array}{l}\text { Subsurface } \\
\text { leak } \\
\text { forming } \\
\text { surface } \\
\text { pool }\end{array}$ & $\begin{array}{l}\text { While conducting a } \\
\text { hydrostatic pressure test } \\
\text { of underground waste } \\
\text { transfer lines in the 241- } \\
\text { s Tank Farm, water was } \\
\text { heard draining into a 241- } \\
\text { s valve pit. sL-119 } \\
\text { leaked to ground forming a } \\
\text { pool of water at the } \\
\text { surface. SL-119 is direct } \\
\text { buried (unencased) line. } \\
\text { The water eroded through } \\
\text { the overlying berm. }\end{array}$ \\
\hline
\end{tabular}


WHC-SD-WM-CN-057, Rev. 0

\begin{tabular}{|c|c|c|c|}
\hline $\begin{array}{l}\text { WHC- } \\
\text { TANKFARM- } \\
1992-40\end{array}$ & $6 / 14 / 92$ & $\begin{array}{l}\text { Subsurface } \\
\text { leak }\end{array}$ & $\begin{array}{l}\text { Transfer line SL-116 in } \\
241-s \text { farm failed hydro } \\
\text { test, waste came out } \\
\text { buried portion of heat } \\
\text { trace conduit near the } \\
\text { line. Cause of line leak } \\
\text { was likely heat stress } \\
\text { induced fatigue. Heat } \\
\text { trace conduit likely } \\
\text { failed due to corrosion. } \\
\text { SL-116 is direct buried } \\
\text { line. }\end{array}$ \\
\hline $\begin{array}{l}\text { WHC- } \\
\text { TANKFARM- } \\
1992-45\end{array}$ & $6 / 10 / 92$ & $\begin{array}{l}\text { Suspected } \\
\text { subsurface } \\
\text { leak }\end{array}$ & $\begin{array}{l}\text { Attempting to hydro test } \\
\text { direct buried transfer } \\
\text { line SL-115, } 200 \text { gallons } \\
\text { more than the calculated } \\
\text { line holdup was added. } \\
\text { Assume line failed. }\end{array}$ \\
\hline $\begin{array}{l}\text { WHC- } \\
\text { TANKFARM- } \\
1995-109\end{array}$ & $11 / 21 / 94$ & $\begin{array}{l}\text { Suspected } \\
\text { subsurface } \\
\text { leak }\end{array}$ & $\begin{array}{l}\text { Pressure test of supernate } \\
\text { transfer line SN- } 246 \\
\text { failed, indicating loss of } \\
\text { integrity. This line is } \\
\text { unencased along some of } \\
\text { its route. }\end{array}$ \\
\hline
\end{tabular}


WHC-SD-WM-CN-057, Rev. 0

APPENDIX B

Calculation of Maximum Bubmersible Pump Transfer Flowrate 


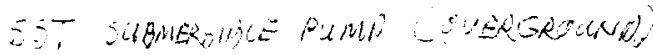

$$
\begin{aligned}
& W H C-S D-W M-C N-O S 7, R+U O
\end{aligned}
$$

Westinghouse

Hanford Company

Page 1

\section{Calculations}

Subject: BX-106 FLYGT B-2600 PUMP RUN-IN PERFORMANCE AGAINST DERIVED OGT SYSTEM CURVE OF THE CONCEPTUAL CONFIGURATION

References: 1. QC INSPECTION RECORD OF WORK ORDER NUMBER 2H9500114F, p. 29 AND ATTACHED CALCULATIONS

2. SCHEMATIC OF BX-106 PUMP PIT PIPING CONFIGURATION FOR OGT SALTWELL PUMPING (H-2-821842 SH 1)

3. FLEXONICS INC., FLEXIBLE METAL HOSE AND FITTINGS, p. 14

4. CAMERON HYDRAULIC DATA, p. 3-8, 3-112, 3-113, 3-118

5. TANK FARM SURVEILLANCE AND WASTE STATUS SUMMARY REPORT FOR SEPTEMBER 1992, p. C-11

6. $\mathrm{H}-2-41348$ and $\mathrm{H}-2-37852$

7. WHC-SD-WM-SAR-034, Rev. 0-A

Objective of Analysis: To show that the pump performance-system configuration operating points for BX-106 OGT saltwell pumping fall within the bounds of WHC-SD-WM-SAR-034, REV 0-A, SECTION 9.0 (ACCIDENT SAFETY ANALYSIS)

Design Input and their Sources: All of the above references

Results of Literature Review: N.A.

Calculations: (Description of calculations to be performed, models and methods used.)

\section{BX-106 SYSTEM CURVE}

The model being developed is the system curve (see attached) for the proposed BX-106 pumping configuration. A submersible pump will be lowered into the tank and then pump waste solution out of the top of the heel pit and transfer the waste to 244-BX. The model developed is for the flow that would result if a catastrophic failure occurred at the location where the piping leaves the heel pit. This is the worst case scenario for the accident analysis described in Section 9.2.1.1 of WHC-SD-WM-SAR-034, Rev 0-A.

The derived system curve will be comprised of the lift from the top of the waste to the top of the heel pit, along with all the resistances along the flow path to the top of the heel pit. Shown are the following calculations for the derived system curve:

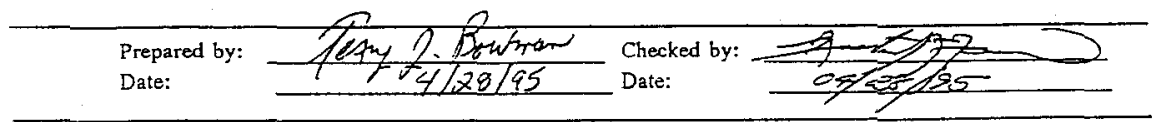

Hanford Operations and Engineering Contractor for the US Department of Energy

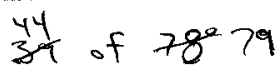




\section{WHC. SO-WM-CN-OS?, ReV}

Westinghouse

\section{Calculations}

Total static head (referenced from beginning waste level in BX-106)

Tank bottom elevation $=614 \mathrm{ft}$. (ref. $\mathrm{H}-2-37852$ )

Waste level from tank bottom $=1.4 \mathrm{ft}$. ( ref. \#5)

Top elevation of $8 X-106$ beel pit $=654.83 \mathrm{ft}$. (ref. H-2-41348)

Total static bead $=654.83-(614+1.4)=39.43 \mathrm{ft}$

\section{Friction Intake Side}

0

\section{Friction Discharge Side}

2 inch pipe:

35 ft standard pipe, $\mathrm{C}=130$ (ref. $\mathrm{H}-2-68521,2$ and ref. 44 p. $3-8$ )

one elbow, 5.17 ft standard pipe (raf ${ }^{4} 4$ p. 3-120)

1 inch pipe:

$6.8 \mathrm{ft}$ standard pipe, $\mathrm{C}=130$ (ref. $\pi 2$ and ref. $\pi 4$ p. $3-8$ )

$4 \mathrm{ft}$ flexible metal hose, at 3 times loss at $\mathrm{C}=130$ (ref. $\pi 3$ and ref. 54 p.3-8)

Valve, $\mathrm{K}=0.69$ (ref. $\# 4$ p. $3-112$ )

Two long radius elbows, $t / d=4, K=0.32$ (ref. $\pi 4$ p. 3-113)

One standard elbow, $K=0.69$

two reducers, 2 in. to 1 in., $45 \mathrm{deg}$ angle, $K=0.23$ (ref. $\# 4$ p. 3-118)

exit loss, $\mathrm{K}=1.0$ (ref. $\ddot{7} 4$ p. $3-116$ )

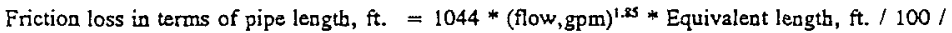

$(C=130$, friction factor for new steel pipe) $1.85 /(d=1.05$ for 1 inch Sch 40 pipe, or $d=2.07$ for 2 inch Sch 40 pipe) ${ }^{4.865 s}$ (ref. $\# 4$ p-3-7) Note: This loss calculation method is conservative for the desired analysis. The above formula is for water at 60 degrees with new pipe. The $\mathrm{BX}-106$ waste solution is a roore viscous than water and would result is more friction loss per unit flow and when combined with the diminished pump performance due to viscosity the resulting flow at the catastrophic break location decreases.

Friction loss in terms of velocity head, ft. $=\mathrm{K} *(\text { velocity, } \mathrm{ft} / \mathrm{sec})^{2} / 2 /(\mathrm{g}=$ gravity constant $=32.2)$ , where velocity, $\mathrm{ft} / \mathrm{sec}=0.408 *\left(\right.$ flow, gpm) $/(\text { d, inside diameter, in. })^{2}$.

Total system bead required of the pump to produce flow at the top of the heel pit during a catastrophic primary line failure $=$ Total static head + friction losses $=39.43 \mathrm{ft}$. +1 inch line losses +2 inch line losses $=39.43$ $\mathrm{ft}+[(6.8+4 * 3)$,straight $1 *$ pipe $+(\mathrm{K}=.69+2 * .32+.69+2 * .23+1)$, velocity head $]+[(35+5.17)$, straight 2 in pipe]

The above equation reduces to the following:

Total system head $=39.43+0.0190 * \mathrm{Q}^{1.85}+0.0074 * \mathrm{Q}^{2}+0.00149 * \mathrm{Q}^{1.25}$ where $\mathrm{Q}$,gFm
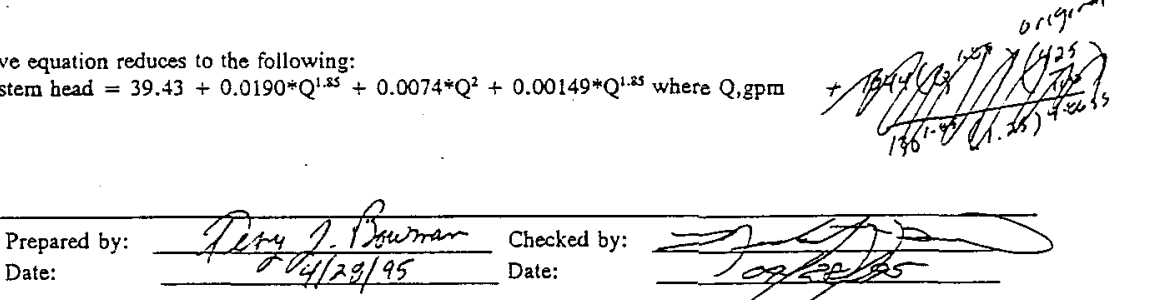

Hanford Operations and Engineering Contractor for the US Department of Energy 


\section{Calculations}

From the total system head equation will be developed a system curve to compare against the run-in tests. $Q$ is varied from 0 to $60 \mathrm{gpm}$ by increments of $10 \mathrm{gpm}$.

\begin{tabular}{ll} 
GPM & Total system head, $\mathrm{ft}$. \\
\cline { 2 - 2 } 0 & 39.43 \\
10 & 41.6 \\
20 & 47.6 \\
30 & 57.2 \\
40 & 70.1 \\
50 & 86.4 \\
60 & 106.0
\end{tabular}

These results are plotted and compared against the pump run-in curve of 4/10/95 (see attached). The nin-in test developed the performance curve of the pump, i.e., total head against flow. The intersection of both curves is the operating point of the pump at the specified parameters, i.e., catastrophic break at top of heel pit.

Note: Both the run-in test and the system curve derivation are for water. The waste solution in the tank has a greater viscosity than water. The resulting intersection of the true field curves would result in less flow and less head than the water-based analysis.

Assumptions:

Drawing $\mathrm{H}-2-41348$ has the most accurate and up to date elevation data. This elevation was surveyed for the drawing and went through QA.

\section{Summary of Results and Conclusions:}

The discharge flow rate at the worst case scenario of a pipe break point right outside the pump pit will amount to less than $50 \mathrm{gpm}$. The pressure head (as water) of the pumping system deadhead is 35 psig. The pump-system configuration of BX-106 is within the bounds of WHC-SD-WM-SAR-034, REV. 0-A, SECTION 9.0 (ACCIDENT SAFETY ANALYSIS), where maximum pressure is 60 psig and maximum flow is $60 \mathrm{gpm}$.

Reviews and Approvals:

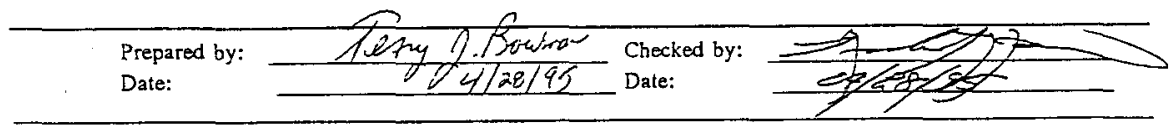

Hanford Operations and Engineering Contractor for the US Department of Energy

$$
\text { 年 of } 7879
$$




\section{BX-106 SYSTEM CURVE}

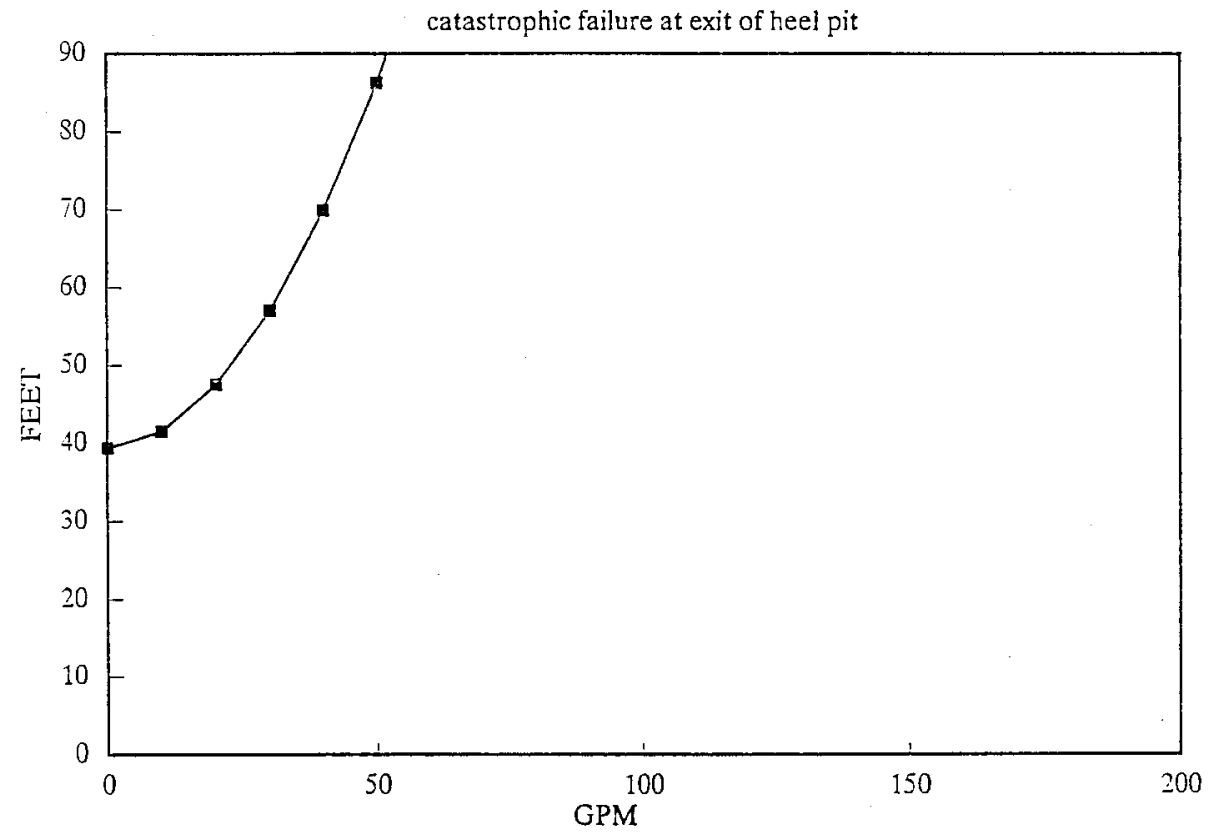

47
$4 x$ of 78979 
FLYGT B-2060 RUN - IN

BX-106 SETUP (4-10-95)

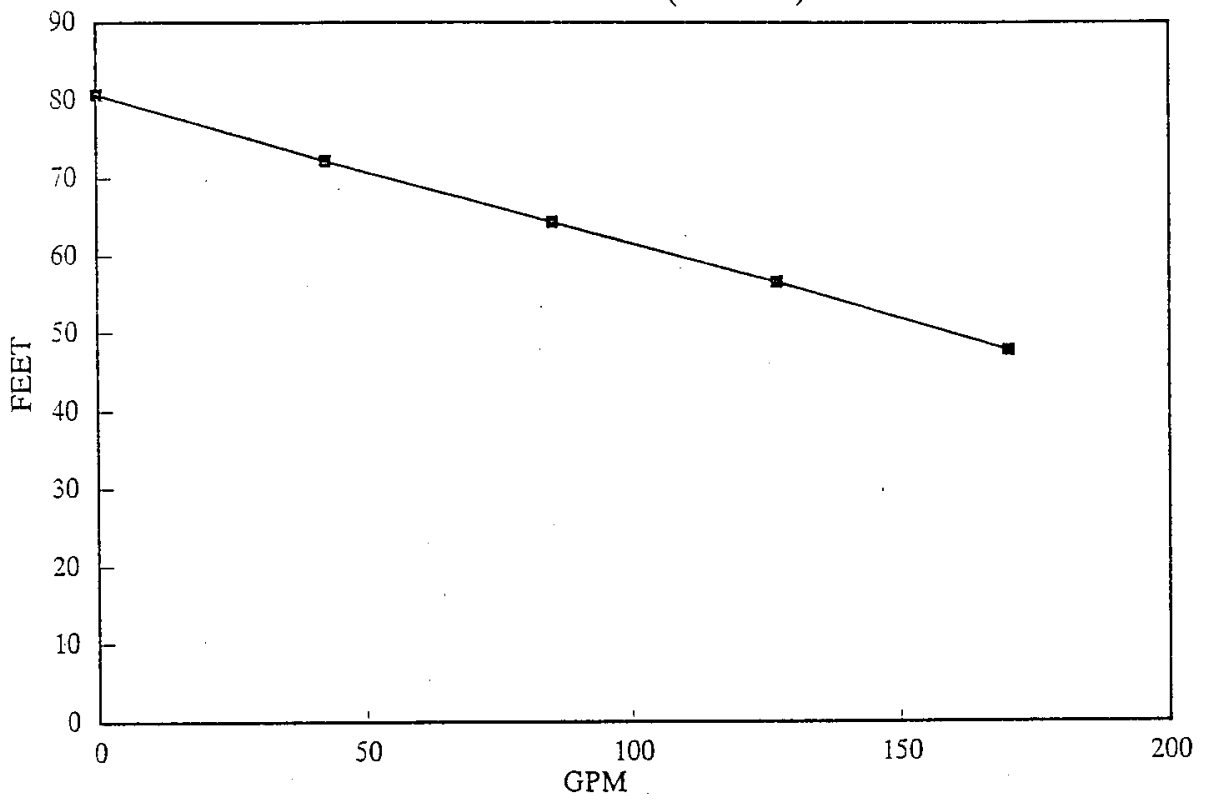


WHC-SD-WH-CN-057, Rev. 0

APPENDIX C

MICROSHIELD output Files

49 of 79 
WHC-SD-WM-CN-057, Rev. 0

CASE 1. MICROSHIELD Input and Output for Direct Shine Due to Gamma Emitters, Unmitigated Accident Scenario

so of 79 
$w+C-50-w M-C N-O S 7$, Rev 0

MicroShield 4.00 - Serial \#4.00-00128

Westinghouse Hanford Company

Page : 1

DOS File: USUBG.MS4

Run Date: September 20, 1996

Run Time: 11:40 a.m. Friday

Duration: $0: 00: 33$

File Ref:

Date:

By:

Checked:

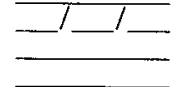

Case Title: unmitigated subsurface leak, dose from gamma emitters

GEOMETRY 7 - Cylinder Volume - Side Shields

centimeters feet and inches

Dose point coordinate $X: \quad 7200.0 \quad 236.0 \quad 2.6$

Dose point coordinate $Y: \quad 164.0 \quad 5.0 \quad 4.6$

Dose point coordinate Z: $\quad 0.0 \quad 0.0 \quad .0$

Cylinder height: $\quad 14.0 \quad 0.0 \quad 5.5$

Cylinder radius: $\quad 2800.0 \quad 91.0 \quad 10.4$

Side Clad: $\quad 4400.0 \quad 144.0 \quad 4.3$

Source Volume: $3.44821 \mathrm{e}+8 \mathrm{~cm}^{\wedge} 3 \quad 12177.2 \mathrm{cu} f \mathrm{ft} .2 .10423 \mathrm{e}+7 \mathrm{cu}$ in.

\begin{tabular}{|c|c|c|c|c|}
\hline & & \multicolumn{3}{|c|}{ MATERIAL DENSITIES $\left(\mathrm{g} / \mathrm{cm}^{\wedge} 3\right)$} \\
\hline Material & $\begin{array}{l}\text { Source } \\
\text { Shield }\end{array}$ & $\begin{array}{l}\text { Transition } \\
\text { Shield }\end{array}$ & $\begin{array}{l}\text { Side Clad } \\
\text { Shield }\end{array}$ & $\begin{array}{l}\text { Immersion } \\
\text { Shield }\end{array}$ \\
\hline $\begin{array}{l}\text { Air } \\
\text { Concrete }\end{array}$ & 1.6 & & Sirsera & \\
\hline & 0.56 & & & \\
\hline
\end{tabular}

BUILDUP

Method: Buildup Factor Tables

The material reference is Transition

INTEGRATION PARAMETERS

Quadrature Order

Radial

Circumferential

10

Axial (along Z)

10

10

SOURCE NUCLIDES

$\begin{array}{lcclcc}\text { Nuclide } & \text { curies } & \mu \mathrm{Ci} / \mathrm{cm}^{\wedge} 3 & \text { Nuclide } & \text { curies } & \mu \mathrm{Ci} / \mathrm{cm}^{\wedge} 3 \\ \text { Ba-137m } & 1.7297 \mathrm{e}+005 & 5.0163 \mathrm{e}+002 & \text { Co-60 } & 5.6757 \mathrm{e}+002 & 1.6460 \mathrm{e}+000 \\ \text { Cs-137 } & 1.8378 \mathrm{e}+005 & 5.3298 \mathrm{e}+002 & \text { Eu-154 } & 1.3514 \mathrm{e}+004 & 3.9190 \mathrm{e}+001\end{array}$

S1 of 79 
WHC-SO-WM-CN-OS7, Rev O

Page : 2

DOS File: USUBG.MS4

Run Date: September 20, 1996

Run Time: 11:40 a.m. Friday

Title : unmitigated subsurface leak, dose from gamma emitters

\begin{tabular}{|c|c|c|c|c|c|}
\hline \multicolumn{6}{|c|}{$==$} \\
\hline $\begin{array}{l}\text { Energy } \\
(\mathrm{MeV})\end{array}$ & $\begin{array}{c}\text { Activity } \\
\text { (photons/sec) }\end{array}$ & $\begin{array}{l}\text { Energy } \mathrm{Fl} \\
(\mathrm{MeV} / \mathrm{sq}\end{array}$ & $\begin{array}{l}\text { Ience Rate } \\
\mathrm{cm} / \mathrm{sec} \text { ) }\end{array}$ & $\begin{array}{r}\text { Exposure } R \\
(m R /\end{array}$ & $\begin{array}{l}\text { te In Air } \\
\text { r) }\end{array}$ \\
\hline & & No Buildup & With Build & No Buildup & With Buildu \\
\hline 0.1 & $2.023 e+014$ & $2.199 \mathrm{e}+001$ & $7.391 e+002$ & $3.365 e-002$ & $1.131 \mathrm{e}+000$ \\
\hline 0.2 & $3.415 \mathrm{e}+013$ & $1.737 \mathrm{e}+001$ & $2.581 \mathrm{e}+002$ & $3.065 \mathrm{e}-002$ & $4.555 e-001$ \\
\hline 0.4 & $3.567 \mathrm{e}+012$ & $7.131 \mathrm{e}+000$ & $4.857 \mathrm{e}+001$ & $1.390 \mathrm{e}-002$ & 9.463 \\
\hline 0.5 & $1.083 e+012$ & $3.320 e+000$ & $1.825 e+001$ & $6.517 e-003$ & 3.582 \\
\hline 0 . & $5.799 \mathrm{e}+015$ & $2.512 \mathrm{e}+004$ & $1.176 \mathrm{e}+005$ & $3 e+001$ & $2.296 \mathrm{e}$ \\
\hline 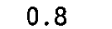 & $1.950 \mathrm{e}+014$ & $1.447 e+003$ & $5.393 e+003$ & $2 e+000$ & $1.026 \mathrm{e}+001$ \\
\hline 1 & $1.748 \mathrm{e}+014$ & $57 e+003$ & $6.272 e+003$ & $e+000$ & $1.156 \mathrm{e}+001$ \\
\hline 1 & $1 e+014$ & $40 e+003$ & $1284 e+004$ & $e+000$ & $2.159 \mathrm{e}+001$ \\
\hline TOTAL: & $\overline{6.626 e+015}$ & $\overline{3.362 \mathrm{e}+004}$ & $\overline{1.432 \mathrm{e}+005}$ & $\overline{6.396 e+001}$ & $\overline{2.747 e+002}$ \\
\hline
\end{tabular}


WHC-SD-WM-CN-057, Rev. 0

CASE 2. MICROSHIELD Input and Output for Direct Shine Due to Bremsstrahlung Radiation, Unmitigated Accident Scenario 
wit C-SD-WM-CN-OS?, RevO

MicroShield 4.00 - Serial \#4.00-00128

Westinghouse Hanford Company

Page : 1

DOS File: USUBBR.MS4

Run Date: September 20, 1996

Run Time: 12:56 p.m. Friday

Duration: $0: 01: 24$
File Ref:

Date:

By:

Checked:

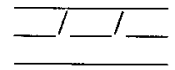

at

Case Title: unmitiged subsurface leak, dose from bremsstrahlung effect

GEOMETRY 7 - Cylinder Volume - Side Shields

Dose point coordinate $X: \quad 7200.0$

Dose point coordinate $Y: \quad 164.0$

Dose point coordinate $Z: \quad 0.0$

Cylinder height: $\quad 14.0$

Cylinder radius: $\quad 2800.0$

Side Clad: $\quad 4400.0$

feet and inches

$236.0 \quad 2.6$

$5.0 \quad 4.6$

$\begin{array}{rr}5.0 & 4.6 \\ 0.0 & .0\end{array}$

$0.0 \quad 5.5$

$91.0 \quad 10.4$

$144.0 \quad 4.3$

Source Volume: $3.44821 \mathrm{e}+8 \mathrm{~cm} \mathrm{~cm}^{\wedge} 12177.2 \mathrm{cu}$ ft. $2.10423 \mathrm{e}+7 \mathrm{cu}$ in.

\begin{tabular}{|c|c|c|c|c|}
\hline & & \multicolumn{3}{|c|}{ MATERIAL DENSITIES $\left(\mathrm{g} / \mathrm{cm}^{\wedge} 3\right)$} \\
\hline Material & $\begin{array}{l}\text { Source } \\
\text { Shield }\end{array}$ & $\begin{array}{l}\text { Transition } \\
\text { Shield }\end{array}$ & $\begin{array}{l}\text { Side Clad } \\
\text { Shield }\end{array}$ & $\begin{array}{l}\text { Immersion } \\
\text { Shield }\end{array}$ \\
\hline $\begin{array}{l}\text { Concrete } \\
\text { Water }\end{array}$ & $\begin{array}{l}1.6 \\
0.56\end{array}$ & & 1.6 & \\
\hline
\end{tabular}

BUILDUP

Method: Buildup Factor Tables

The material reference is Transition

Radial

Circumferential

Axial (along $Z$ )

INTEGRATION PARAMETERS

Quadrature Order

10

10

10

SOURCE WAS ENTERED AS ENERGIES ONLY 
WHC-SD-WM-CN-OS7, ReVO

Page : 2

DOS File: USUBBR.MS4

Run Date: September 20, 1996

Run Time: 12:56 p.m. Friday

TitTe : unmitiged subsurface leak, dose from bremsstrahlung effect

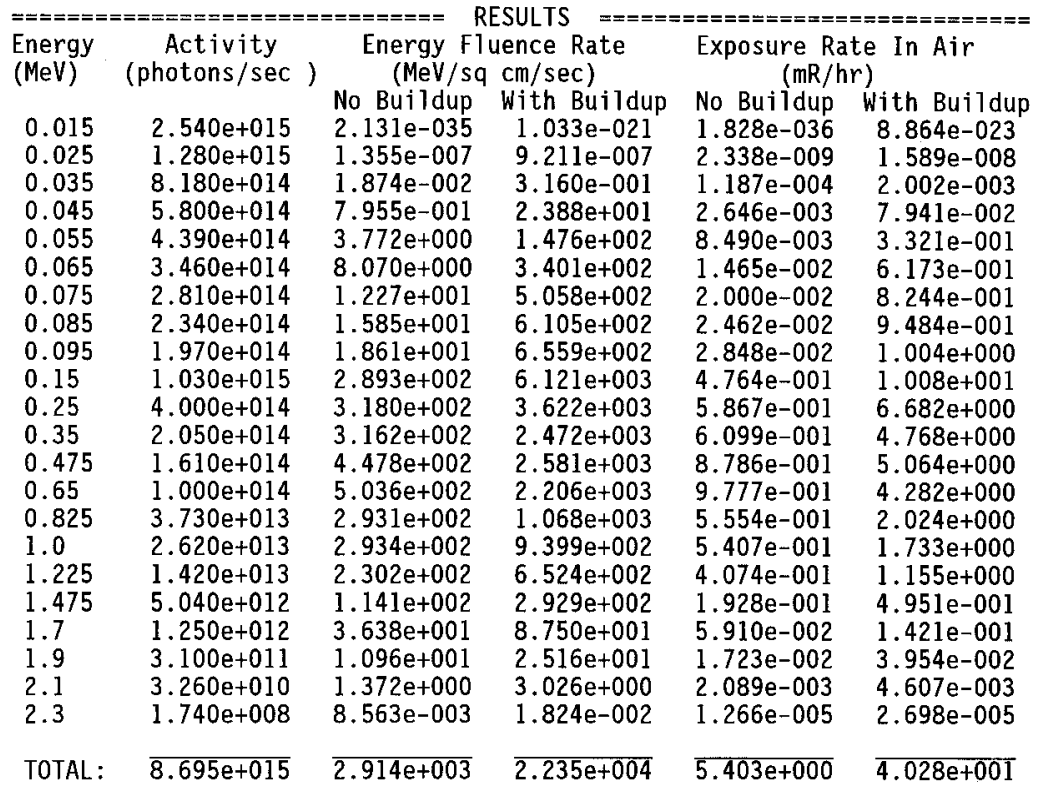


WHC-SD-WM-CN-057, Rev. 0

CASE 3. MICROSHIELD Input and Output For Direct Shine Due to Gamma Emitters, Mitigated Accident Scenario 


$$
W H C-S D-W M-C N-O S T \text {, ReVO }
$$

MicroShield 4.00 - Serial \#4.00-00128

Page : 1

DOS File: USUBG.MS4

Run Date: September 20, 1996

Run Time: $1: 18 \mathrm{p} . \mathrm{m}$. Friday

Duration: $0: 00: 28$

File Ref:

Date:

Checked:

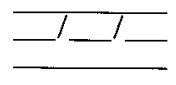

Case Title: unmitigated subsurface leak, dose from gamma emitters

\begin{tabular}{rccc}
\multicolumn{2}{r}{ GEOMETRY 7 - Cylinder Volume } & Side Shields \\
centimeters & feet and inches \\
Dose point coordinate X: & 8730.0 & 286.0 & 5.0 \\
Dose point coordinate Y: & 152.24 & 4.0 & 11.9 \\
Dose point coordinate Z: & 0.0 & 0.0 & .0 \\
Cylinder height: & 2.54 & 0.0 & 1.0 \\
Cylinder radius: & 1270.0 & 41.0 & 8.0 \\
Side Clad: & 7460.0 & 244.0 & 9.0
\end{tabular}

Source Volume: $1.28704 \mathrm{e}+7 \mathrm{~cm}^{\wedge} 3454.513 \mathrm{cu} \mathrm{ft}$. 785398. cu in.

\begin{tabular}{|c|c|c|c|c|}
\hline \multirow{2}{*}{$\begin{array}{l}\text { Material } \\
\text { Air }\end{array}$} & \multirow[b]{2}{*}{$\begin{array}{l}\text { Source } \\
\text { Shield }\end{array}$} & \multicolumn{3}{|c|}{ MATERIAL DENSITIES $\left(\mathrm{g} / \mathrm{cm}^{\wedge} 3\right)$} \\
\hline & & $\begin{array}{l}\text { Transition } \\
\text { ShieId }\end{array}$ & $\begin{array}{l}\text { Side Clad } \\
\text { Shield }\end{array}$ & $\begin{array}{l}\text { Immersion } \\
\text { Shield }\end{array}$ \\
\hline Air & & & & \\
\hline
\end{tabular}

BUILDUP

Method: Buildup Factor Tables

The material reference is Transition

$\begin{array}{lc} & \text { INTEGRATION PARAMETERS } \\ \text { Quadrature Order } \\ \text { Radial } & 10 \\ \text { Circumferential } & 10 \\ \text { Axial (along Z) } & 10\end{array}$

\begin{tabular}{|c|c|c|c|c|c|}
\hline & & SOU & NUCL IDES & & \\
\hline ucl ide & $\begin{array}{l}\text { cur } \\
1.5676 \\
1.675\end{array}$ & $\begin{array}{c}\mu \mathrm{Ci} / \mathrm{cm}^{*} 3 \\
1.2180 \mathrm{e}+003 \\
1.3020 \mathrm{e}+003\end{array}$ & $\begin{array}{l}\text { Nucl ide } \\
\text { Co-60 } \\
\text { Eu-154 }\end{array}$ & $\begin{array}{c}\text { curies } \\
5.1351 \mathrm{e}+001 \\
1.2162 \mathrm{e}+003\end{array}$ & $\begin{array}{l}m^{\wedge} 3 \\
e+000 \\
e+001\end{array}$ \\
\hline
\end{tabular}


Page : 2

WHC-SD-WM-CN-OS7, Rev 0

DOS File: USUBG.MS4

Run Date: September 20, 1996

Run Time: 1:18 p.m. Friday

Title : unmitigated subsurface leak, dose from gamma emitters

\begin{tabular}{|c|c|c|c|c|c|}
\hline $\begin{array}{l}\text { Energy } \\
(\mathrm{MeV})\end{array}$ & $\begin{array}{c}\text { Activity } \\
\text { (photons/sec) }\end{array}$ & $\begin{array}{l}\text { Energy Fl } \\
(\mathrm{MeV} / \mathrm{sq}\end{array}$ & $\begin{array}{l}\text { Jence Rate } \\
\mathrm{cm} / \mathrm{sec} \text { ) }\end{array}$ & $\begin{array}{r}\text { Exposure R } \\
(\mathrm{mR} /\end{array}$ & $\begin{array}{l}\text { te In Air } \\
\text { r) }\end{array}$ \\
\hline $\begin{array}{l}0.0575 \\
0.246 \\
0.4426 \\
0.5907 \\
0.6631 \\
0.8723 \\
1.0024 \\
1.2618 \\
1.3325 \\
1.5767\end{array}$ & $\begin{array}{l}7.192 \mathrm{e}+013 \\
3.073 \mathrm{e}+012 \\
4.185 \mathrm{e}+011 \\
2.805 \mathrm{e}+012 \\
5.343 \mathrm{e}+014 \\
6.314 \mathrm{e}+012 \\
1.279 \mathrm{e}+013 \\
1.855 \mathrm{e}+013 \\
1.900 \mathrm{e}+012 \\
1.586 \mathrm{e}+012\end{array}$ & $\begin{array}{l}\text { No Buildup } \\
1.573 \mathrm{e}+001 \\
9.280 \mathrm{e}+000 \\
3.608 \mathrm{e}+000 \\
4.064 \mathrm{e}+001 \\
9.539 \mathrm{e}+003 \\
1.851 \mathrm{e}+002 \\
4.826 \mathrm{e}+002 \\
1.063 \mathrm{e}+003 \\
1.202 \mathrm{e}+002 \\
1.360 \mathrm{e}+002\end{array}$ & $\begin{array}{c}\text { With Buildup } \\
2.825 \mathrm{e}+002 \\
8.545 \mathrm{e}+001 \\
2.013 \mathrm{e}+001 \\
1.828 \mathrm{e}+002 \\
3.958 \mathrm{e}+004 \\
6.449 \mathrm{e}+002 \\
1.552 \mathrm{e}+003 \\
3.022 \mathrm{e}+003 \\
3.324 \mathrm{e}+002 \\
3.476 \mathrm{e}+002\end{array}$ & $\begin{array}{l}\text { No Buildup } \\
3.311 \mathrm{e}-002 \\
1.707 \mathrm{e}-002 \\
7.066 \mathrm{e}-003 \\
7.939 \mathrm{e}-002 \\
1.849 \mathrm{e}+001 \\
3.483 \mathrm{e}-001 \\
8.892 \mathrm{e}-001 \\
1.869 \mathrm{e}+000 \\
2.085 \mathrm{e}-001 \\
2.257 \mathrm{e}-001\end{array}$ & $\begin{array}{c}\text { With Buildup } \\
5.945 \mathrm{e}-001 \\
1.572 \mathrm{e}-001 \\
3.941 \mathrm{e}-002 \\
3.570 \mathrm{e}-001 \\
7.671 \mathrm{e}+001 \\
1.213 \mathrm{e}+000 \\
2.859 \mathrm{e}+000 \\
5.312 \mathrm{e}+000 \\
5.767 \mathrm{e}-001 \\
5.769 \mathrm{e}-001\end{array}$ \\
\hline TOTAL: & $\overline{6.537 \mathrm{e}+014}$ & $\overline{1.159 \mathrm{e}+004}$ & +004 & $2.217 \mathrm{e}+001$ & $8.840 \mathrm{e}+001$ \\
\hline
\end{tabular}


WHC-SD-WM-CN-057, Rev. 0

CASE 4. MICROSHIELD Input and Output for Direct Shine Due to Bremsstrahlung Radiation, Mitigated Accident Scenario 


$$
\text { WHC-SP-WM-CN-OS7, ReVO }
$$

MicroShield 4.00 - Serial \#4.00-00128

Westinghouse Hanford Company

Page : 1

DOS File: MSUBBR.MS4

Run Date: September 23, 1996

Run Time: 8:54 a.m. Monday

Duration: 0:01:02
File Ref:

Date:

By:

Checked:

Case Title: mitigated subsurface leak, dose from bremsstrahlung effect

Dose point coordinate $X$ :

GEOMETRY 7 - Cylinder Volume - Side Shields

Dose point coordinate $Y$ :

Dose point coordinate $Z$ :

Cylinder height:

Cylinder radius: $\quad 1270.0$

Side Clad: $\quad 7460.0$

feet and inches

8730.0

152.54

0.0

2.54

1270.0

286.0

5.0

0.0

0.0

41.0

244.0

5.0

.1

.0

1.0

8.0

9.0

Source Volume: $1.28704 \mathrm{e}+7 \mathrm{~cm} \wedge 3454.513 \mathrm{cu} \mathrm{ft}$. 785398. cu in.

\begin{tabular}{|c|c|c|c|c|}
\hline \multirow[b]{2}{*}{ Material } & \multirow{3}{*}{$\begin{array}{l}\text { Source } \\
\text { Shield }\end{array}$} & \multicolumn{3}{|c|}{ MATERIAL DENSITIES $\left(\mathrm{g} / \mathrm{cm}^{\wedge} 3\right)$} \\
\hline & & Transition & Side Clad & Immersion \\
\hline & & $\begin{array}{l}\text { Shield } \\
0.00122\end{array}$ & Shield & $\begin{array}{l}\text { Shield } \\
0.00122\end{array}$ \\
\hline $\begin{array}{l}\text { Concrete } \\
\text { Water }\end{array}$ & 14 & & 1.6 & \\
\hline
\end{tabular}

BUILDUP

Method: Buildup Factor Tables

The material reference is Transition

Radial

Circumferential

Axial (along $\mathrm{Z}$ )

INTEGRATION PARAMETERS

Quadrature Order

10

10

10

SOURCE WAS ENTERED AS ENERGIES ONLY 
Page : 2

DOS File: MSUBBR.MS4

Run Date: September 23, 1996

Run Time: 8:54 a.m. Monday

Title : mitigated subsurface leak, dose from bremsstrahlung effect

\begin{tabular}{|c|c|c|c|c|c|}
\hline $\begin{array}{l}===== \\
\text { Energy } \\
\text { (MeV) }\end{array}$ & $\begin{array}{c}=========== \\
\text { Activity } \\
\text { (photons/sec) }\end{array}$ & \multicolumn{2}{|c|}{ Energy Fluence Rate } & \multicolumn{2}{|c|}{$\begin{array}{c}\text { Exposure Rate In Air } \\
(\mathrm{mR} / \mathrm{hr})\end{array}$} \\
\hline & & Buildup & With Buildu & No Buildup & With Buildup \\
\hline 0.0 & $2.300 \mathrm{e}+014$ & $459 e-007$ & $7.424 \mathrm{e}-007$ & $3.824 e-008$ & $6.368 \mathrm{e}-008$ \\
\hline & 1. & $2.975 \mathrm{e}-001$ & $1.043 \mathrm{e}+000$ & $5.131 \mathrm{e}-003$ & $1.800 \mathrm{e}-002$ \\
\hline & $0 e+013$ & $2.958 \mathrm{e}+000$ & $2.114 \mathrm{e}+001$ & $1.874 \mathrm{e}-002$ & $1.339 \mathrm{e}-001$ \\
\hline 0.0 & $60 e+013$ & $5.938 e+000$ & $7.290 \mathrm{e}+001$ & $1.975 \mathrm{e}-002$ & $2.424 \mathrm{e}-001$ \\
\hline 0.0 & $30 e+013$ & $7.857 \mathrm{e}+000$ & $1.337 \mathrm{e}+002$ & $1.768 \mathrm{e}-002$ & $3.010 \mathrm{e}-001$ \\
\hline 0.065 & $40 e+013$ & $8.993 e+000$ & $1.796 e+002$ & $1.633 \mathrm{e}-002$ & $3.261 \mathrm{e}-001$ \\
\hline 0.075 & $10 \mathrm{e}+013$ & $9.641 \mathrm{e}+000$ & $2.032 \mathrm{e}+002$ & $1.571 \mathrm{e}-002$ & $3.312 \mathrm{e}-001$ \\
\hline 0.085 & $2.120 \mathrm{e}+013$ & $1.012 \mathrm{e}+001$ & $2.126 \mathrm{e}+002$ & $1.573 \mathrm{e}-002$ & $3.303 e-001$ \\
\hline 0.095 & $90 e+013$ & $1.041 \mathrm{e}+001$ & $2.110 \mathrm{e}+002$ & $1.593 e-002$ & $3.228 \mathrm{e}-001$ \\
\hline 0.15 & $0 e+013$ & $1.197 e+002$ & $1.746 \mathrm{e}+003$ & $1.972 \mathrm{e}-001$ & $2.875 e+000$ \\
\hline 0.25 & $0 \mathrm{e}+013$ & $1.130 \mathrm{e}+002$ & $1.026 \mathrm{e}+003$ & $2.086 \mathrm{e}-001$ & $1.892 \mathrm{e}+000$ \\
\hline 0.35 & $0 e+013$ & $1.055 \mathrm{e}+002$ & $7.118 \mathrm{e}+002$ & $2.035 \mathrm{e}-001$ & $1.373 e+000$ \\
\hline 0.475 & $0 \mathrm{e}+013$ & $1.432 \mathrm{e}+002$ & $7.566 \mathrm{e}+002$ & $2.809 \mathrm{e}-001$ & $1.484 \mathrm{e}+000$ \\
\hline 0.65 & $0+012$ & $1.570 \mathrm{e}+002$ & $6.604 \mathrm{e}+002$ & $3.048 \mathrm{e}-001$ & $1.282 \mathrm{e}+000$ \\
\hline 0.825 & $\mathrm{e}+012$ & $9.004 \mathrm{e}+001$ & $3.243 \mathrm{e}+002$ & $1.706 \mathrm{e}-001$ & $6.146 \mathrm{e}-001$ \\
\hline 1.0 & $\mathrm{e}+012$ & $8.958 \mathrm{e}+001$ & $2.884 \mathrm{e}+002$ & $1.651 \mathrm{e}-001$ & $5.317 \mathrm{e}-001$ \\
\hline 1.225 & $0 \mathrm{e}+012$ & $7.018 \mathrm{e}+001$ & $2.026 \mathrm{e}+002$ & $1.242 \mathrm{e}-001$ & $3.585 \mathrm{e}-001$ \\
\hline 1.475 & $0 \mathrm{e}+011$ & $3.488 \mathrm{e}+001$ & $9.191 \mathrm{e}+001$ & $5.896 \mathrm{e}-002$ & $1.553 \mathrm{e}-001$ \\
\hline 1.7 & $0 e+011$ & $22 \mathrm{e}+001$ & $2.775 \mathrm{e}+001$ & $1.822 \mathrm{e}-002$ & $4.508 e-002$ \\
\hline 1.9 & $e+010$ & $3.375 \mathrm{e}+000$ & $7.978 \mathrm{e}+000$ & $5.303 e-003$ & $1.253 \mathrm{e}-002$ \\
\hline 2.1 & 2. & $1 e-001$ & $9.660 \mathrm{e}-001$ & $6.474 \mathrm{e}-004$ & $1.471 \mathrm{e}-003$ \\
\hline 2.3 & 1. & $38 e-003$ & $5.855 \mathrm{e}-003$ & $3.945 \mathrm{e}-006$ & $8.659 \mathrm{e}-006$ \\
\hline TOTAL: & $\overline{7.884 e+014}$ & $\overline{9.943 e+002}$ & $\overline{6.879 e+003}$ & $\overline{1.863 e+000}$ & $\overline{1.263 \mathrm{e}+001}$ \\
\hline
\end{tabular}


WHC-SD-WM-CN-057, Rev. 0

APRENDIX D

BREMCAIC Data

62 of 79 
Photon Production Rates for Sr-90/Y-90 in Mixtures using BREMCALC (photons per second from 1 curie of each isotope)

\begin{tabular}{|c|c|c|c|c|c|}
\hline $\begin{array}{l}\text { Midpoi } \\
\text { nt } \\
\text { Energy }\end{array}$ & $2:=\frac{4 a t}{6}=60$. & $\begin{array}{c}\text { Paper } \\
\mathrm{z}=6.35\end{array}$ & $\begin{array}{c}\mathrm{Air} \\
\mathrm{z}=7.36\end{array}$ & 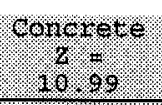 & $\begin{array}{c}\text { AlZr } \\
Z= \\
33.38 \\
\end{array}$ \\
\hline 0.015 & $7.80 \mathrm{~s}+68 \mathrm{~s}$ & $7.59 \mathrm{E}+08$ & $8.56 \mathrm{E}+08$ & $1.244 \mathrm{r}+09$ & $3.72 \mathrm{E}+0$ \\
\hline 0.025 & 3.9 .98 .708 & $3.87 E+08$ & $4.35 \mathrm{E}+08$ & $6.26=9 \cdot 08$ & $1.88 \mathrm{E}+0$ \\
\hline 0.035 & $2.5661+08$ & $2.48 \mathrm{E}+08$ & $2.79 \mathrm{E}+08$ & $3.99=8-103$ & $\begin{array}{c}19 \mathrm{E}+0 \\
9\end{array}$ \\
\hline 0.045 & $1.82 \mathrm{~F}+108$ & $1.77 E+08$ & $1.98 \mathrm{E}+08$ & $2.8 \mathrm{~s}=-08$ & $\begin{array}{c}8.42 \mathrm{E}+0 \\
8\end{array}$ \\
\hline 0.055 & 1.38 .87 .8 .8 & $1.34 \mathrm{E}+08$ & $1.50 \mathrm{E}+08$ & $2.0 .4=10.8 ?$ & $6.34 \mathrm{E}+0$ \\
\hline 0.065 & $1.0039+08$ & $1.06 \mathrm{E}+08$ & $1.19 \mathrm{E}+08$ & $1.69=1-08$ & $\begin{array}{c}4.98 \mathrm{E}+0 \\
8\end{array}$ \\
\hline 0.075 & 6. $9197+07$ & $8.66 \mathrm{E}+07$ & $9.67 \mathrm{E}+07$ & 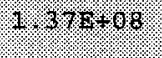 & $\begin{array}{c}4.03 \mathrm{E}+0 \\
8\end{array}$ \\
\hline 0.085 & $=7: 42 \mathrm{st}+07$ & $7.21 \mathrm{E}+07$ & $8.05 E+07$ & $1.1+102: 00$ & $\begin{array}{c}3.34 \mathrm{E}+0 \\
8\end{array}$ \\
\hline 0.095 & 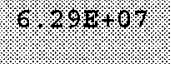 & $6.11 \mathrm{E}+07$ & $6.82 \mathrm{E}+07$ & $9.6712+107$ & $\begin{array}{c}2.81 \mathrm{E}+0 \\
8\end{array}$ \\
\hline 0.15 & 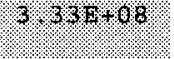 & $3.24 \mathrm{E}+08$ & $3.60 \mathrm{E}+08$ & $5.03 \mathrm{E}: 08$ & $\begin{array}{c}1.45 E+0 \\
9\end{array}$ \\
\hline 0.25 & $4.32 \mathrm{E}+68$ & $1.29 \mathrm{E}+08$ & $1.42 \mathrm{E}+08$ & $1.95=7.008$ & $\begin{array}{c}5.50 \mathrm{E}+0 \\
8\end{array}$ \\
\hline 0.35 & $6.88 \mathrm{a} \cdot 97$ & $6.71 \mathrm{E}+07$ & $7.37 \mathrm{E}+07$ & 9.9807 .07 & $\begin{array}{c}2.74 \mathrm{E}+0 \\
8\end{array}$ \\
\hline 0.475 & $5.96 \mathrm{er}+07$ & $5.38 \mathrm{E}+07$ & $5.87 \mathrm{E}+07$ & $7.84 \mathrm{n}=097$ & $\begin{array}{c}2.10 \mathrm{E}+0 \\
8\end{array}$ \\
\hline 0.65 & $3.53 x+40$ & $3.46 \mathrm{E}+07$ & $3.75 \mathrm{E}+07$ & $4: 897=4.07$ & $\begin{array}{c}1.26 \mathrm{E}+0 \\
8\end{array}$ \\
\hline 0.825 & 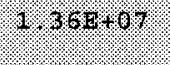 & $1.33 \mathrm{E}+07$ & $1.43 \mathrm{E}+07$ & 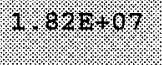 & $\begin{array}{c}4.49 \mathrm{E}+0 \\
7\end{array}$ \\
\hline 1 & $9.82 \mathrm{R}+106$ & $9.66 \mathrm{E}+06$ & $1.03 E+07$ & $1.28 .98+0 \%$ & $\begin{array}{c}3.02 \mathrm{E}+0 \\
7\end{array}$ \\
\hline 1.225 & 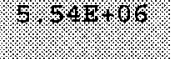 & $5.46 \mathrm{E}+06$ & $5.75 \mathrm{E}+06$ & $6.9=07=106$ & $\begin{array}{c}1.53 E+0 \\
7\end{array}$ \\
\hline 1.475 & $\frac{2}{2} .068+96$ & $2.03 \mathrm{E}+06$ & $2.12 \mathrm{E}+06$ & $2.968+06$ & $\begin{array}{c}4.94 \mathrm{E}+0 \\
6\end{array}$ \\
\hline 1.7 & 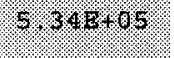 & $5.29 \mathrm{E}+05$ & $5.45 \mathrm{E}+05$ & $6.4 \div 2=1.05$ & I. I IE+0 \\
\hline 1.9 & 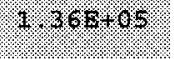 & $1.35 \mathrm{E}+05$ & $1.38 \mathrm{E}+05$ & 1.51 .0 .05 & $\begin{array}{c}2.46 \mathrm{E}+0 \\
5\end{array}$ \\
\hline 2.1 & 1.4901964 & $1.48 \mathrm{E}+04$ & $1.50 \mathrm{E}+04$ & $1.59=8.04$ & $2 \cdot 3 \frac{1 E}{4}+0$ \\
\hline 2.3 & 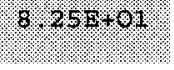 & $8.23 E+O 1$ & $8.28 \mathrm{E}+\mathrm{O} 1$ & 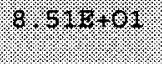 & $\begin{array}{c}1.05 \mathrm{E}+0 \\
2\end{array}$ \\
\hline
\end{tabular}


WHC-SD-WM-CN-057, Rev. 0

APPENDIX E

MICROSKYSHINE Output Files

64 of 79 
WHC-SD-WM-CN-057, Rev. 0

CASE 1. MICROSKYSHINE Output for Unmitigated Accident, Dose due to Gamma Emitters 


$$
W H C-S D-W M-C N-O S 7, R \in U . C
$$

\section{Microskyshine}

(Nuclear \& Radiological Safety Analysis - 1.16-007)

Page: 1

File: UPOOLG.SKY

Run: 9:49 a.m.

: August 6,1996
File Ref:

Date:

By:

Checked:

CASE: pool $28 \mathrm{~m}$ in radius, dose due to gamma emitters

.GEOMETRY: Vertical cylinder area source behind a wall

DIMENSIONS (meters):

Distance between wall and detector......... X Depth of source behind wa $11 \ldots \ldots \ldots \ldots \ldots \ldots$ y

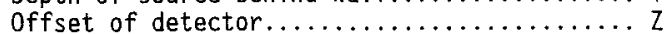

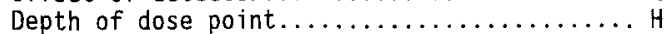
Distance between center of source and wall... RI Thickness of cover slab................. Tl Thickness of second shield............... T2

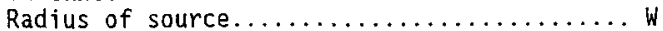
Height of source.................

43.

0.855

0 .

0.645

29.

0 .

0 .

28.

0.14

\section{INTEGRATION PARAMETERS:}

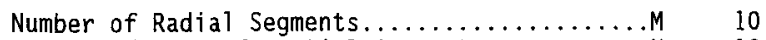

Number of Circumferentia] Segments..........N 10

Number of Vertical Segments.............. 10

Quadrature order................... 16

MATERIAL DENSITIES $(\mathrm{g} / \mathrm{cc})$ :

Ambient air: .0012

\begin{tabular}{lccc} 
Material & Cover Slab & Lower Shield & Volume Source \\
\hline Air & & & 0.56 \\
Water & & & 1.6 \\
Concrete & & \\
Iron & & \\
Lead & & \\
Zirconium & & & \\
Urania & & &
\end{tabular}

Buildup factor based on: AIR. 


$$
\text { WHC-SD-WM-CN-OS?, iev }
$$

Page 2

CASE: poot $28 \mathrm{~m}$ in radius, dose due to gamma emitters SOURCE NUCLIDES:

\begin{tabular}{llll} 
Nuclide & \multicolumn{1}{c}{ Curies } & Nuclide & \multicolumn{1}{c}{ Curies } \\
\hdashline $\mathrm{Ba}-137 \mathrm{~m}$ & $1.7297 \mathrm{e}+05$ & $\mathrm{Co-60}$ & $5.6757 \mathrm{e}+02$ \\
$\mathrm{Cs}-137$ & $1.8378 \mathrm{e}+05$ & Eu -154 & $1.3514 \mathrm{e}+04$
\end{tabular}

RESULTS:

\begin{tabular}{ccccc}
$\begin{array}{c}\text { Group } \\
\#\end{array}$ & $\begin{array}{c}\text { Energy } \\
\text { (mev) }\end{array}$ & $\begin{array}{c}\text { Activity } \\
\text { (photons/sec) }\end{array}$ & $\begin{array}{c}\text { Dose point } \\
\text { rads/photon }\end{array}$ & $\begin{array}{c}\text { Dose rate } \\
\text { (mr/hr) }\end{array}$ \\
\hdashline 1 & -1.30 & $2.212 \mathrm{e}+14$ & $4.452 \mathrm{e}-20$ & $4.062 \mathrm{e}+01$ \\
2 & 1.03 & $1.656 \mathrm{e}+14$ & $4.690 \mathrm{e}-20$ & $3.202 \mathrm{e}+01$ \\
3 & .84 & $9.181 \mathrm{e}+13$ & $4.529 \mathrm{e}-20$ & $1.714 \mathrm{e}+01$ \\
4 & .66 & $5.905 \mathrm{e}+15$ & $4.837 \mathrm{e}-20$ & $1.178 \mathrm{e}+03$ \\
5 & .48 & $4.881 \mathrm{e}+12$ & $5.144 \mathrm{e}-20$ & $1.035 \mathrm{e}+00$ \\
6 & .40 & $1.047 \mathrm{e}+12$ & $4.968 \mathrm{e}-20$ & $2.145 \mathrm{e}-01$ \\
7 & .24 & $3.301 \mathrm{e}+13$ & $5.133 \mathrm{e}-20$ & $6.987 \mathrm{e}+00$ \\
8 & .20 & $1.136 \mathrm{e}+12$ & $5.008 \mathrm{e}-20$ & $2.346 \mathrm{e}-01$ \\
9 & .12 & $2.023 \mathrm{e}+14$ & $3.954 \mathrm{e}-20$ & $3.299 \mathrm{e}+01$ \\
10 & & & & \\
11 & & & & \\
12 & & & & \\
13 & & & & \\
14 & & & & \\
15 & & & & \\
16 & & & & \\
17 & & & & \\
18 & & & & \\
19 & & & &
\end{tabular}


WHC-SD-WM-CN-057, Rev. 0

CASE 2. MICROSKYSHINE Output for Unmitigated Accident, Dose Due to Bremmstrahlung Radiation 


$$
W H C-S D-W M-C N-O S 7, R e V O
$$

\section{MicroSkyshine}

(Nuclear \& Radiological Safety Analysis $\begin{array}{r}1.16-007) \\ \text { File Ref: }\end{array}$
Page: 1
File: USUBBR.SKY
Run: $12: 41 \mathrm{p}$.m.
$\begin{aligned} \text { : August } 12,1996 & \text { Checked: }\end{aligned}$

CASE: poo $28 \mathrm{~m}$ in radius, $14 \mathrm{~cm}$ deep, dose due to bremmstahlung GEOMETRY: Vertical cylinder area source behind a wall

\section{DIMENSIONS (meters):}

Distance between wall and detector.......... X Depth of source behind wa $11 \ldots \ldots \ldots \ldots \ldots \ldots$.

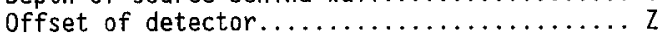

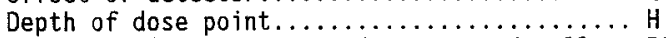
Distance between center of source and wa11... RI Thickness of cover slab................. T1 Thickness of second shield............... T2 Radius of source......................W

Height of source.................. 0.14

43.

0.855

0 .

0.645

29.

0 .

0 .

28.

\section{INTEGRATION PARAMETERS:}

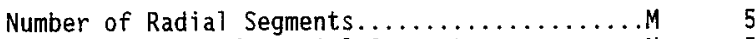

Number of Circumferential Segments..........N 5

Number of Vertical Segments............... 5

Quadrature order................... 15

MATERIAL DENSITIES $(\mathrm{g} / \mathrm{cc})$ :

Ambient air: .0012

\begin{tabular}{|c|c|c|c|}
\hline Material & Cover Slab & Lower Shield & Volume Source \\
\hline $\begin{array}{l}\text { Air } \\
\text { Water } \\
\text { Concrete } \\
\text { Iron } \\
\text { Lead } \\
\text { Zirconium } \\
\text { Urania }\end{array}$ & & & $\begin{array}{l}0.56 \\
1.6\end{array}$ \\
\hline
\end{tabular}

Buildup factor based on: AIR. 


$$
\text { WHC-SD-WM-CN-OS, LEU }
$$

Page 2

CASE: poo $128 \mathrm{~m}$ in radius, $14 \mathrm{~cm}$ deep, dose due to bremmstahlung SOURCE NUCLIDES:

Source was entered by energy groups.

\section{RESULTS:}

\begin{tabular}{ccccc}
$\begin{array}{c}\text { Group } \\
\#\end{array}$ & $\begin{array}{c}\text { Energy } \\
\text { (mev) }\end{array}$ & $\begin{array}{c}\text { Activity } \\
\text { (photons/sec) }\end{array}$ & $\begin{array}{c}\text { Dose point } \\
\text { rads/photon }\end{array}$ & $\begin{array}{c}\text { Dose rate } \\
(\mathrm{mr} / \mathrm{hr})\end{array}$ \\
\hdashline 1 & -1.90 & $-3.100 \mathrm{e}+11$ & $4.051 \mathrm{e}-20$ & $5.178 \mathrm{e}-02$ \\
2 & 1.70 & $1.250 \mathrm{e}+12$ & $4.015 \mathrm{e}-20$ & $2.070 \mathrm{e}-01$ \\
3 & 1.48 & $5.040 \mathrm{e}+12$ & $3.966 \mathrm{e}-20$ & $8.242 \mathrm{e}-01$ \\
4 & 1.23 & $1.420 \mathrm{e}+13$ & $4.576 \mathrm{e}-20$ & $2.679 \mathrm{e}+00$ \\
5 & 1.00 & $2.620 \mathrm{e}+13$ & $4.670 \mathrm{e}-20$ & $5.045 \mathrm{e}+00$ \\
6 & .82 & $3.730 \mathrm{e}+13$ & $4.495 \mathrm{e}-20$ & $6.914 \mathrm{e}+00$ \\
7 & .65 & $1.000 \mathrm{e}+14$ & $4.898 \mathrm{e}-20$ & $2.020 \mathrm{e}+01$ \\
8 & .47 & $1.610 \mathrm{e}+14$ & $5.152 \mathrm{e}-20$ & $3.420 \mathrm{e}+01$ \\
9 & .35 & $2.050 \mathrm{e}+14$ & $4.815 \mathrm{e}-20$ & $4.070 \mathrm{e}+01$ \\
10 & .25 & $4.000 \mathrm{e}+14$ & $5.158 \mathrm{e}-20$ & $8.508 \mathrm{e}+01$ \\
11 & .15 & $1.030 \mathrm{e}+15$ & $4.651 \mathrm{e}-20$ & $1.975 \mathrm{e}+02$ \\
12 & & & & \\
13 & & & & \\
14 & & & & \\
15 & & & & \\
16 & & & & \\
17 & & & & \\
18 & & & & \\
19 & & & & \\
20 & & --20 & &
\end{tabular}


WHC-SD-WM-CN-057, Rev. 0

CASE 3. MICROSKYSHINE Output for Mitigated Accident, Dose Due to Gamma Emitters 


\section{Microskyshine}

$====3======:=$

(Nuclear \& Radiological Safety Analysis - 1.16-007)

Page: 1

File: MPOOLG.SKY

Run: $11: 36 \mathrm{a} \cdot \mathrm{m}$.

: August 8,1996
File Ref:

Date:

By:

Checked:

CASE: mit poot, $r=12.7 \mathrm{~m}$, dose from gamma radiation

GEOMETRY: Vertical cylinder area source behind a wail

\section{DIMENSIONS (meters):}

Distance between wall and detector.......... X Depth of source behind wall................ Y offset of detector.......................... $z$ Depth of dose point..................... Distance between center of source and wal1... RI Thickness of cover slab.................. Tl Thickness of second shield............... T2 Radius of source......................W Height of source...................... L

73.6

0.396

0 .

$-1.1$

13.7

0.

0.

12.7

0.0254

\section{INTEGRATION PARAMETERS:}

Number of Radial Segments.................. 10

Number of Circumferential Segments...........N 10

Number of Verticat Segments................. 10

Quadrature Order........................ 16

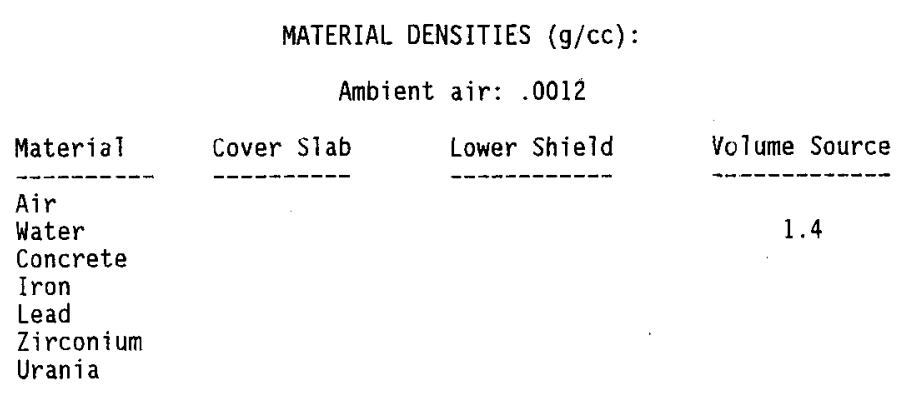

Buildup factor based on: AIR. 
CASE: mit pool, $r=12.7 \mathrm{~m}$, dose from gamma radiation SOURCE NUCLIDES:

\begin{tabular}{|c|c|c|c|}
\hline Nucl ide & Curies & Nucl ide & Curies \\
\hline $\begin{array}{l}\mathrm{Ba}-137 \mathrm{~m} \\
\mathrm{Cs}-137\end{array}$ & $\begin{array}{l}1.5676 \mathrm{e}+04 \\
1.6757 \mathrm{e}+04\end{array}$ & $\begin{array}{l}\text { Co-60 } \\
\text { Eu-154 }\end{array}$ & $\begin{array}{l}5.1351 \mathrm{e}+01 \\
1.2162 \mathrm{e}+03\end{array}$ \\
\hline
\end{tabular}

RESULTS:

\begin{tabular}{ccccc}
$\begin{array}{c}\text { Group } \\
\#\end{array}$ & $\begin{array}{c}\text { Energy } \\
\text { (mev) }\end{array}$ & $\begin{array}{c}\text { Activity } \\
\text { (photons/sec) }\end{array}$ & $\begin{array}{c}\text { Dose point } \\
\text { rads/photon }\end{array}$ & $\begin{array}{c}\text { Dose rate } \\
\text { (mr } / \mathrm{hr} \text { ) }\end{array}$ \\
\hdashline 1 & -1.30 & $1.992 \mathrm{e}+13$ & $-8.491 \mathrm{e}-20$ & $6.975 \mathrm{e}+00$ \\
2 & 1.03 & $1.491 \mathrm{e}+13$ & $8.870 \mathrm{e}-20$ & $5.453 \mathrm{e}+00$ \\
3 & .84 & $8.263 \mathrm{e}+12$ & $8.525 \mathrm{e}-20$ & $2.939 \mathrm{e}+00$ \\
4 & .66 & $5.351 \mathrm{e}+14$ & $9.004 \mathrm{e}-20$ & $1.986 \mathrm{e}+02$ \\
5 & .48 & $4.392 \mathrm{e}+11$ & $9.404 \mathrm{e}-20$ & $1.703 \mathrm{e}-01$ \\
6 & .40 & $9.424 \mathrm{e}+10$ & $9.139 \mathrm{e}-20$ & $3.551 \mathrm{e}-02$ \\
7 & .24 & $2.971 \mathrm{e}+12$ & $9.101 \mathrm{e}-20$ & $1.115 \mathrm{e}+00$ \\
8 & .20 & $1.022 \mathrm{e}+11$ & $8.892 \mathrm{e}-20$ & $3.748 \mathrm{e}-02$ \\
9 & .12 & $1.821 \mathrm{e}+13$ & $7.763 \mathrm{e}-20$ & $5.828 \mathrm{e}+00$ \\
10 & & & & \\
11 & & & & \\
12 & & & & \\
13 & & & & \\
14 & & & & \\
15 & & & & \\
16 & & & \\
17 & & & & \\
18 & & & & \\
19 & & & & \\
20 & & & &
\end{tabular}

TOTALS: $\quad 6.000 \mathrm{e}+14$

$2.212 \mathrm{e}+02$ 
WHC-SD-WM-CN-057, Rev. 0

CASE 4. MICROSKYSHINE Output Mitigated Accident, Dose Due to Bremsstrahlung Radiation 
$W H C-S D-W M-C N-O S 7$, ReV 0

\section{MicroSkyshine}

\section{$===========3$}

Page: 1

File: MSUBBR.SKY

Run: 9:53 a.m.

: September 23, 1996

(Nuclear \& Radiological Safety Analysis - 1.16-007)
File Ref:

Date:

By:

Checked:

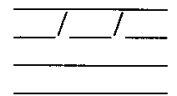

CASE: mit pool, $r=12.7 \mathrm{~m}$, dose from bremmstrahlung radiation

GEOMETRY: Vertical cylinder area source behind a wall

\section{DIMENSIONS (meters):}

Distance between wall and detector......... X

Depth of source behind wall............... r

0 ffset of detector.................... $z$

73.6

Depth of dose point........................

0.396

Distance between center of source and wal1... R1

Thickness of cover slab.................. T1

Thickness of second shield................ T2

13.7

Radius of source........................W

0 .

0.

Height of source.................... $\quad 0.0254$

\section{INTEGRATION PARAMETERS:}

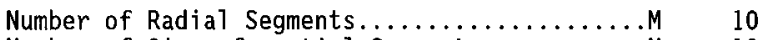

Number of Circumferential Segments.........N 10

Number of Vertical Segments.............. 10

Quadrature 0 rder.................... 16

\section{MATERIAL DENSITIES $(\mathrm{g} / \mathrm{cc})$ :}

Ambient air: .0012

\begin{tabular}{lccc} 
Material & Cover Slab & Lower Shie1d & Volume Source \\
\hdashline Air & & & 1.4 \\
Water & & \\
Concrete & & \\
Iron & & \\
Lead & & \\
Zirconium & & \\
Urania & &
\end{tabular}

Buildup factor based on: AIR. 


\section{Page 2}

WHC-SD-WM-CN-OS?, Rev 0

CASE: mit pool, $r=12.7 \mathrm{~m}$, dose from bremmstrahlung radiation SOURCE NUCLIDES:

\begin{tabular}{llll} 
Nuclide & \multicolumn{1}{c}{ Curies } & Nuclide & \multicolumn{1}{c}{ Curies } \\
\hdashline $\mathrm{Ba}-137 \mathrm{~m}$ & $\mathbf{1 . 5 6 7 6 \mathrm { e } + 0 4}$ & $-\mathrm{C} 0-60$ & $5.1351 \mathrm{e}+01$ \\
$\mathrm{Cs}-137$ & $1.6757 \mathrm{e}+04$ & Eu-154 & $1.2162 \mathrm{e}+03$
\end{tabular}

RESULTS:

\begin{tabular}{|c|c|c|c|c|}
\hline$\underset{\#}{\text { Group }}$ & $\begin{array}{l}\text { Energy } \\
\text { (mev) }\end{array}$ & $\begin{array}{c}\text { Activity } \\
\text { (photons/sec) }\end{array}$ & $\begin{array}{l}\text { Dose point } \\
\text { rads/photon }\end{array}$ & $\begin{array}{c}\text { Dose rate } \\
(\mathrm{mr} / \mathrm{hr})\end{array}$ \\
\hline $\begin{array}{r}1 \\
2 \\
3 \\
4 \\
5 \\
6 \\
7 \\
8 \\
9 \\
10 \\
11 \\
12 \\
13 \\
14 \\
15 \\
16 \\
17 \\
18 \\
19 \\
20\end{array}$ & $\begin{array}{l}1.90 \\
1.70 \\
1.48 \\
1.23 \\
1.00 \\
.82 \\
.65 \\
.47 \\
.35 \\
.25 \\
.15\end{array}$ & $\begin{array}{l}2.810 \mathrm{e}+10 \\
1.140 \mathrm{e}+11 \\
4.580 \mathrm{e}+11 \\
1.290 \mathrm{e}+12 \\
2.380 \mathrm{e}+12 \\
3.390 \mathrm{e}+12 \\
9.100 \mathrm{e}+12 \\
1.460 \mathrm{e}+13 \\
1.860 \mathrm{e}+13 \\
3.630 \mathrm{e}+13 \\
9.360 \mathrm{e}+13\end{array}$ & $\begin{array}{l}7.909 \mathrm{e}-20 \\
7.861 \mathrm{e}-20 \\
7.782 \mathrm{e}-20 \\
8.694 \mathrm{e}-20 \\
8.855 \mathrm{e}-20 \\
8.582 \mathrm{e}-20 \\
9.084 \mathrm{e}-20 \\
9.396 \mathrm{e}-20 \\
8.881 \mathrm{e}-20 \\
9.102 \mathrm{e}-20 \\
8.417 \mathrm{e}-20\end{array}$ & $\begin{array}{l}9.164 \mathrm{e}-03 \\
3.695 \mathrm{e}-02 \\
1.470 \mathrm{e}-01 \\
4.624 \mathrm{e}-01 \\
8.690 \mathrm{e}-01 \\
1.200 \mathrm{e}+00 \\
3.409 \mathrm{e}+00 \\
5.657 \mathrm{e}+00 \\
6.811 \mathrm{e}+00 \\
1.362 \mathrm{e}+01 \\
3.249 \mathrm{e}+01\end{array}$ \\
\hline & OTALS: & $1.799 e+14$ & & $6.471 \mathrm{e}+01$ \\
\hline
\end{tabular}


WHC-SD-WM-CN-057, Rev. 0

\author{
APPENDIX F \\ Peer Review Checklist
}

77 of 79 


\section{WHC-SD-WM-CN-057 ReV.O}

\section{CHECKLIST FOR TECHNICAL PEER REVIEW}

A.

B.

\section{Yes No* NA}

Calculation Notes for Subsurface Leak Resulting in Pool, TWRS FSAR Accident Analysis, WHC-SD-WM-CN-057, Rev. 0, Brett Hall, 9/19/96

Scope of Review: Entire document

Problem completely defined.

Accident scenarios developed in a clear and logical manner. Necessary assumptions explicitly stated and supported. Computer codes and data files documented.

Data used in calculations explicitly stated in document. Data checked for consistency with original source information as applicable.

[x] [ ] [ ] Mathematical derivations checked including dimensional consistency of results.

[x] [ ] [ ] Models appropriate and used within range of validity or use outside range of established validity justified.

[x] [ ] [ ]

$[x]\left[\begin{array}{lll}{[} & {[}\end{array}\right]$

[x] [ ] [ ]

$[x]\left[\begin{array}{l}{[x]} \\ {[x]}\end{array}\right]$

[x] [ ] [ ]

$[x][x] * *$ Review calculations, comments, and/or notes are attached.

[x] [ ] [ ] Document approved (i.e., the reviewer affirms the technica] accuracy of the document).

[x] [ ] [ ] Traceability

$\frac{\text { Donuld R. Horter } 2 \text { Donald R. Prten }}{\text { Reviewer (Printed Name and Signature) }}$

* A11 "NO" responses must be explained below or on an additional page. ** Any calculations, comments, or notes generated as part of this review should be signed, dated and attached to this checklist. Such material should be labeled and recorded in such a manner as to be intelligible to a technically qualified third party. 
WHC-SD-WM CN-057 reN.0

\section{PEER REVIEW CHECKLIST}

Document Reviewed: WHC-SD-WM-CN-057

Author: B. Hall

Date: September 1996

Scope of Review: Direct shine and skyshine dose calculations, (Section $2.4 .3,2.4 .4,3.4 .3,3.4 .4$ and Appendices $C$, $D$, and $E$

$\frac{\text { Yes No NA }}{[x][1]}$

$\left.\begin{array}{lll}x] & {[} & {[}\end{array}\right]$

$\ll][][$ ]

区] [ ] [ ]

[X] [ ] [ ]

$x \in\left[\begin{array}{ll}x \\ x\end{array}\right]\left[\begin{array}{ll}1 \\ 0\end{array}\right]$

[ ] [ ] $\mathbb{X}]$

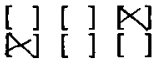

$\circledast[$ [ ] [ ]

[ ] [ ] [ [ $[x]$

[ ] [ ] [ [X]

[X] [ ] [ ] Document approved.

J.c. Van Keuren \&C Vanku Reviewer (Printed Name and Signature) this review, with no gaps.

Problem completely defined. as applicable. consistency of results. reported in document reviewed. checked against references. limits. problem statement. other standards

Previous reviews complete and cover analysis, up to scope of

Accident scenarios developed in a clear and logical manner.

Necessary assumptions explicitly stated and supported.

Computer codes and data files documented.

Data used in calculations explicitly stated in document.

Data checked for consistency with original source information

Mathematical derivations checked including dimensional

Models appropriate and used within range of validity or use outside range of established validity justified.

Hand calculations checked for errors. Spreadsheet results should be treated exactly the same as hand calculations. Software input correct and consistent with document reviewed. Software output consistent with input and with results

Limits/criteria/guidelines applied to analysis results are appropriate and referenced. Limits/criteria/guidelines

Safety margins consistent with good engineering practices. Conclusions consistent with analytical results and applicable

Results and conclusions address 211 points required in the

Format consistent with appropriate NRC Regulatory Guide or

Review calculations, comments, and/or notes are attached. 


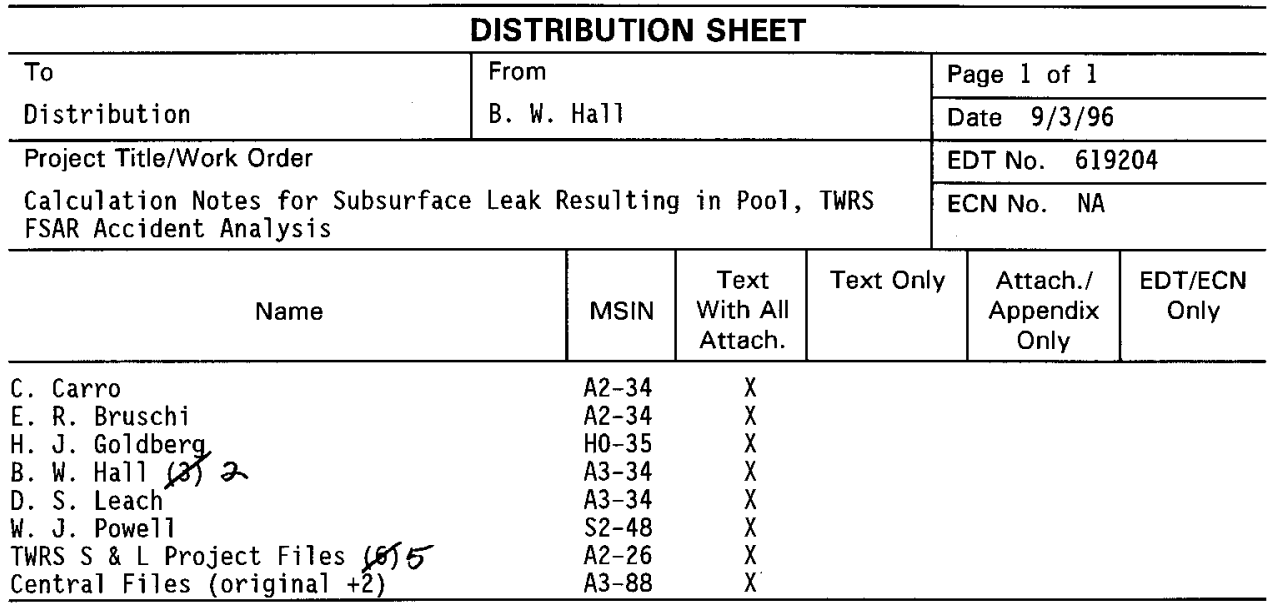

$$
\begin{array}{r}
\text { * Advanced Distribution: * BWHAll } \mathrm{A3}-34(1) \\
\text { *TWRSPrig F. A2-26(1) }
\end{array}
$$

A-6000-135 (01/93) WEF067 